02 Royal Netherlands Institute for Sea Research

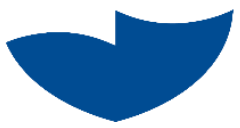

This is a preprint of:

van Oevelen, D.; Duineveld, G.; Lavaleye, M.S.S.; Kutti, T.\& Soetaert, K. (2018). Trophic structure of cold-water coral communities revealed from the analysis of tissue isotopes and fatty acid composition. Marine Biology Research, 14, 287-306

Published version: https://doi.org/10.1080/17451000.2017.1398404

Link NIOZ Repository: http://www.vliz.be/imis?module=ref\&refid=294522

[Article begins on next page]

The NIOZ Repository gives free access to the digital collection of the work of the Royal Netherlands Institute for Sea Research. This archive is managed according to the principles of the Open Access Movement, and the Open Archive Initiative. Each publication should be cited to its original source - please use the reference as presented.

When using parts of, or whole publications in your own work, permission from the author(s) or copyright holder(s) is always needed. 


\section{Trophic structure of cold-water coral communities revealed from the 2 analysis of tissue isotopes and fatty acid composition}

3 Dick van Oevelen ${ }^{1, *}$, Gerard C. A. Duineveld ${ }^{2}$, Marc S. S. Lavaleye ${ }^{2}$, Tina

$4 \mathrm{Kutti}^{3}$, Karline Soetaert ${ }^{1}$

$5{ }^{1}$ NIOZ Royal Netherlands Institute for Sea Research, Department of Estuarine and Delta

6 Systems, and Utrecht University, Yerseke, The Netherlands, Dick.van.Oevelen@nioz.nl;

$7 \quad$ Karline.Soetaert@,nioz.nl

$8{ }^{2}$ NIOZ Royal Netherlands Institute for Sea Research, Department of Ocean Systems, and

9 Utrecht University, Texel, The Netherlands, Gerard.Duineveld@nioz.nl;

10 Marc.Lavaleye@nioz.nl

$11{ }^{3}$ Institute of Marine Research (IMR), Benthic resources and processes, Bergen, Norway,

12 Tina.Kutti@imr.no

$13 *$ Corresponding author

Acknowledgements. The crew from the R/V 'GO Sars', R/V ' $\mathrm{H}$. Mosby' and R/V 'Pelagia' are thanked for their skilled support during the sampling campaigns. Nanne van Hoytema is thanked for his help during sampling at Belgica Mounds. Pieter van Rijswijk and the technicians from the analytical lab are thanked for the many fatty acid extractions and isotope analyses. This research was supported by the CoralFISH project funded by the European Commission under the Seventh Framework Programme (FP7) Theme 6: Environment; Activity 6.2: Sustainable management of Resources (Grant agreement no: 213144), HERMES project (Contract no. GOCE-CT-2005-511234) funded by the European Commission's Sixth Framework Program under the priority ‘Sustainable Development, Global Change and Ecosystems', and by VIDI grant 864.13.007 (NWO, The Netherlands). All data in this paper are available in PANGAEA (doi: will be generated and inserted upon acceptance of the paper during print proofing stage). 
30 Trophic structure of cold-water coral communities revealed from the analysis of tissue 31 isotopes and fatty acid composition

The trophic structure of cold-water coral reef communities at two contrasting locations, the 800-m deep Belgica Mounds (Irish margin) and 300-m deep Træna reefs (Norwegian Shelf), was investigated using stable isotope $\left(\delta^{13} \mathrm{C}\right.$ and $\left.\delta^{15} \mathrm{~N}\right)$ and fatty-acid composition analysis. A broad range of specimens, with emphasis on (commercial) fish species, and organic matter sources were sampled using a variety of tools. Irrespective of the environmental and geographical setting, the $\delta^{15} \mathrm{~N}$ values indicated that the food web encompasses roughly 1.5 to 3 trophic levels. Mobile echinoderms, i.e. sea urchins and sea stars, had highest $\delta^{15} \mathrm{~N}$ values, indicative of a high trophic position in the food web. The fraction of bacterial fatty acids in reef fauna was generally low $(<5 \%)$, indicating that enhanced bacterial production in the water column through seafloor seepage of nutrients ('hydraulic theory') does not form a significant energy pathway into the food web. The high fraction of algal and essential fatty acids in reef fauna and fish at both locations indicates a close coupling with surface productivity, but the transport mechanism depends on the hydrographic setting. At Træna, Calanus copepods and euphausiids form an additional link between primary production and fish, which is largely absent at Belgica Mounds. At Belgica Mounds, the reef community is primarily supported by phytodetritus, as evidenced by the high contribution of algal fatty acids in faunal tissue and seasonal chlorophyll $a$ deposition and marine snow at the reef. The environmental setting of cold-water coral reefs influences the structure of the associated food web.

Keywords: Cold-water coral reefs; food web; carbon isotopes; nitrogen isotopes; fatty acid composition 


\section{Introduction}

55 Cold-water corals build carbonate reef structures in the deep-sea (Roberts et al. 2006) that

56 form a substrate for a diverse (Henry \& Roberts 2007) and active (Van Oevelen et al. 2009;

57 Wagner et al. 2011; White et al. 2012) reef community. Typical members of this community

58 are the polychaete Eunice norvegica (Mueller et al. 2013; Roberts 2005), encrusting and

59 massive sponges (Van Soest \& Lavaleye 2005), squat lobsters, soft-corals, gorgonians,

60 hydroids, crabs and sea stars (Duineveld et al. 2007). In addition to these sessile or low-

61 mobility species, demersal, e.g. tusk (Brosme brosme) and Norway redfish (Sebastes

62 viviparus), and pelagic, e.g. saithe (Pollachius virens), fish species occur in high densities on

63 and around cold-water coral reefs (Biber et al. 2014; Costello et al. 2005; Husebø et al. 2002;

64 Kutti et al. 2015). Although these studies found high fish densities on cold-water coral reefs,

65 it is unclear whether this is related to higher food availability, e.g. a high macrobenthic

66 biomass (Van Oevelen et al. 2009), or related to shelter provided by the physical complexity

67 of the reef (Auster 2005; Husebø et al. 2002). Hence, to better understand the function of

68 cold-water coral reefs it is imperative to unravel the food web structure and take important

69 (commercial) fish species into account.

70 Cold-water coral communities are supported by phytodetritus (Duineveld et al. 2007;

71 Kiriakoulakis et al. 2004; Van Oevelen et al. 2009), though various studies suggest that also

72 zooplankton contributes to their nutrition (Dodds et al. 2009; Husebø et al. 2002;

73 Kiriakoulakis et al. 2005; Naumann et al. 2011; Van Oevelen et al. 2009). Another organic

74 matter source may be bacterioplankton of which the production is stimulated by mucus

75 release by the cold-water corals (Wild et al. 2008). Deep sponge communities are also

76 capable of chemoautotrophic carbon fixation through symbiotic nitrification (Hoffmann et al.

77 2009; van Duyl et al. 2008). Finally, classical predatory interactions are relevant for species

78 like carrier crabs, sea stars, sea urchins and tusk (Duineveld et al. 2007; Husebø et al. 2002; 
79 Stevenson \& Rocha 2013; Van Oevelen et al. 2009).

80 The importance of these various food supply pathways for a cold-water coral reef may

81 be influenced by the environmental setting in which the reef grows (Mienis et al. 2007;

82 Thiem et al. 2006). The interaction of corals mounds with tidal currents may induce

83 downwelling of nutrient-rich surface waters towards the reef mounds (Davies et al. 2009;

84 Duineveld et al. 2012; Soetaert et al. 2016), which may increase the importance of fresh

85 phytodetritus in their nutrition. Other coral mounds may either be too small to induce

86 downwelling or grow in an environment with a unidirectional current or where tidal currents

87 are less prominent. Zooplankton migrates vertically in the water column to feed on

88 phytoplankton during the night and to find shelter from predators in darker deeper waters

89 during the day (Hays 2003). This diel vertical migration pattern was inferred above a cold-

90 water coral reef from a 'rising' backscatter signal at dusk and a 'descending' backscatter

91 signal at dawn in the Gulf of Mexico (Hebbeln et al. 2014; Mienis et al. 2012). Hebbeln et al.

92 (2014) inferred that zooplankton migrated to depths of 500 to $600 \mathrm{~m}$ where the cold-water

93 corals are found. Deeper reefs may however be outside the zooplankton migration window

94 and the biomass of zooplankton decreases exponentially with water depth (Angel \& de C.

95 Baker 1982). Zooplankton may therefore become progressively less important as a resource

96 for deeper reefs. Hence, cold-water coral communities may be supported through different

97 pathways, but it is not straightforward to decipher the importance of these pathways for a reef

98 food web.

Stable isotope measurements of faunal tissue have provided valuable information on

100 deep-sea food web structures including cold-water coral communities (D'Onghia et al. 2010;

101 Duineveld et al. 2007; Kiriakoulakis et al. 2005; Sherwood et al. 2008), since an organism's

$102 \delta^{13} \mathrm{C}$ value reflects that of its basal resource, while its $\delta^{15} \mathrm{~N}$ value is indicative of the trophic 
103 position in the food web. More detailed information on diet composition can be obtained

104 from the composition of individual fatty acids in an organism (Dalsgaard et al. 2003; Kelly \&

105 Scheibling 2012). Fatty acids are the main constituents of lipids, which are found in cell

106 membranes and are used as energy storage. Primary producers (Dijkman \& Kromkamp

107 2006), bacteria (Boschker \& Middelburg 2002) and zooplankton (Dalsgaard et al. 2003)

108 contain specific individual fatty acids or have a unique fatty acid signature. Consumers of the

109 resources modify these fatty acids only to a limited extent and therefore the fatty acid

110 composition of the consumer is a representative mix of its resources (Iverson et al. 2004). In

111 addition, some fatty acids are coined 'essential', as fish have no or very limited capacity to

112 biosynthesize this group of fatty acids and must obtain them from their diet (Arts et al. 2001;

113 Kelly \& Scheibling 2012). Invertebrates have the capacity to synthesize these fatty acids and

114 may therefore form an important link in the food web. Diets of marine organisms can

115 therefore be qualitatively inferred from the concentration and spectrum of its fatty acid

116 composition (Dodds et al. 2009; Kelly \& Scheibling 2012).

117 In this paper, we combine tissue stable isotope and fatty acid composition analysis to

118 investigate food web relations in cold-water coral communities of the Belgica Mounds (Irish

119 Sea) and of the Træna Deep Coral reef field on the Norwegian continental shelf. These study

120 sites are located along the European continental margin and have among the highest densities

121 of cold-water corals around the world (Roberts et al. 2006), but contrast in their

122 environmental setting with differences in water depth, mound size and hydrography. The

123 main goal of this study is to explore the importance of the detrital, zooplankton, bacterial and

124 chemoautotrophic pathways for these cold-water coral communities, with emphasis on

125 demersal and pelagic fish populations. 


\section{Materials and methods}

\section{Study areas and sampling strategy}

128 The Træna Deep Coral Reef field lies within the regional Marine Protected Area (MPA) and

129 is located south of the Lofoten peninsula on the Norwegian continental shelf on the northern

130 slope of the inner Trænadjupet Trough at 270 to $450 \mathrm{~m}$ depth (Fig. 1A). The MPA of 460

$131 \mathrm{~km}^{2}$ has a high abundance of coral reefs. In a detailed survey of a large part of this region

$132\left(307 \mathrm{~km}^{2}\right)$, a total of 1447 long-tailed reefs have been identified from multi-beam bathymetric

133 maps, each being 100-150 $\mathrm{m}$ long, 25-55 $\mathrm{m}$ wide and on average $7 \mathrm{~m}$ high and covering

134 about $2 \%$ of the seafloor of the MPA (Lindberg et al. 2004). The hydrography of the

135 Norwegian shelf is influenced by two northward directed current systems. The North Atlantic

136 Current (NAC) transports comparatively warm saline North Atlantic Water (NAW)

137 northward along the continental shelf edge, while the Norwegian Coastal Current (NCC)

138 transports cold, less saline, Norwegian Coastal Water (NCW) northward along the coast. The

139 reefs within the Træna field are aligned parallel to the main current direction with a live

140 Lophelia pertusa front that faces the current. The greatest density of coral reefs is found on

141 the southern and western/northwestern edge of a circular depression (Fig. 1A). In addition to

142 the cold-water coral reefs, dense aggregations of demosponges, i.e. Geodia barretti, $G$.

143 atlantica, G. macandrewii, Phakellia spp. and Mycale spp., are found in between the reefs

144 (Kutti et al. 2013). Mean bottom water temperature measured in the northern part of the coral

145 MPA $\left(66^{\circ} 58.31 \mathrm{~N}, 11^{\circ} 07.76 \mathrm{E}\right)$ was $6.9^{\circ} \mathrm{C}$ (May 2011) and $7.2^{\circ} \mathrm{C}$ (March 2010) and salinity

146 was around 35 (35.2 in May 2011 and 35.2 in March 2010). Sampling at the Træna reefs was

147 conducted during various cruises to the northern part of the reef aggregation (Fig. 1A), where

148 the water depth ranges between 270 and $320 \mathrm{~m}$.

149 Tissue samples of invertebrates and fish of the Træna CWC reefs were collected on a 
150 research cruise that was conducted from 4 to 16 March 2010 with R/V GO Sars. Demersal

151 fish (i.e. Hippoglossoides platessoides, Chimaera monstrosa, Phycis blennoides, Sebastes

152 viviparus, Argentina sphyraena, Artediellus atlanticus, Trisopterus esmarkii) were collected

153 using a Campelen 1800 bottom trawl just outside the coral MPA $\left(66^{\circ} 56.65 \mathrm{~N}, 11^{\circ} 29.15 \mathrm{E}\right)$.

154 Krill (i.e. Meganyctiphanes norvegica and Thysanoessa inermis), cephalopods (Sepiola

155 atlantica), shrimps (Pandalus borealis) and pelagic fish (i.e. Maurolicus muelleri) were

156 collected using a pelagic krill trawl $\left(66^{\circ} 58.24 \mathrm{~N}, 11^{\circ} 27.82 \mathrm{E}\right)$. Brosme brosme was caught with

157 a bottom long-line on a research cruise with M/S Atlantic (3-9 March 2010, 66 ${ }^{\circ} 57.85 \mathrm{~N}$,

$158 \quad 11^{\circ} 05.23$ E). Samples of Lophelia pertusa, suspended matter, zooplankton and Pollachius

159 virens were collected between 26 and 31 May 2011 during a cruise with R/V Håkon Mosby.

160 Water samples from 30 and 300 m depth were collected using Niskin water sampling bottles

161 and filtered through Whatmann GF/F filters (5 to 10 litres per filter) to collect suspended

162 matter $\left(66^{\circ} 58.31 \mathrm{~N}, 11^{\circ} 07.76 \mathrm{E}\right)$. Zooplankton was sampled $\left(66^{\circ} 58.47 \mathrm{~N}, 11^{\circ} 05.72 \mathrm{E}\right)$ using a

163 WP2 plankton net, towed from $100 \mathrm{~m}$ depth to the surface, which was subsequently sieved

164 through a 280 and $50 \mu \mathrm{m}$ sieve to obtain two (large and small, respectively) zooplankton size

165 classes. Microscope investigation later revealed that both size classes contained almost

166 exclusively Calanus sp. Pollachius virens was caught at $300 \mathrm{~m}$ water depth using a long-line

$167\left(66^{\circ} 58.97 \mathrm{~N}, 11^{\circ} 05.11 \mathrm{E}\right)$. Lophelia pertusa was collected using the ROV Aglantha $\left(66^{\circ} 58.31\right.$

$\left.168 \mathrm{~N}, 11^{\circ} 07.76 \mathrm{E}\right)$. Smaller macrofauna was sampled with a square boxcorer $(30 \mathrm{x} 30 \mathrm{~cm})$. Long-

169 lines, box cores, plankton hauls and water samples were taken within the dense clusters of

170 reefs at Træna (i.e. $<10 \mathrm{~m}$ away from the Lophelia pertusa framework). Trawling is banned

171 within the coral MPA and was therefore carried out $4 \mathrm{~km}$ east of the area (Fig. 1A).

172 The Belgica Mounds are the southernmost coral mound province of the Porcupine

173 Seabight and are located on the south-eastern slope of the Porcupine Basin (Fig. 1B). The

174 mound province consists of outcropping carbonate mounds on the steepest part of the slope at 
175 a depth of 750 to $850 \mathrm{~m}$ and of several isolated mounds (e.g. Galway and Therese Mounds)

176 on the deeper and flatter part of the slope around $950 \mathrm{~m}$ depth. The isolated mounds are

177 located in an area of enhanced near-bottom currents, are oriented parallel or slightly oblique

178 to the slope of the margin and are around $1.5 \mathrm{~km}$ long and up to $100 \mathrm{~m}$ high (Dorschel et al.

179 2007). Another important feature of the coral mounds at the Rockall and Porcupine

180 continental margin is related to their hydrography, which has a wide spectrum of tidally

181 driven flow that includes bottom-trapped baroclinic motions of diurnal period and semi-

182 diurnal tides (Mienis et al. 2007; Mohn et al. 2014). Tissue samples of invertebrates and fish

183 were collected at Belgica Mounds during the HERMES research cruises with the R/V Pelagia

184 in 2008 and $2009\left(51^{\circ} 27^{\prime} \mathrm{N}, 11^{\circ} 45^{\prime} \mathrm{W}\right.$ at a depth between 836 and $\left.970 \mathrm{~m}\right)$. Larger macrofauna

185 was collected with a triangular dredge near the coral reef, while the smaller fauna was

186 sampled with a NIOZ boxcorer with a core diameter of $50 \mathrm{~cm}$. During the 2008 cruise,

187 additional zooplankton and near-bottom suspended particulate matter (SPM) samples were

188 collected. Zooplankton was collected in the upper $200 \mathrm{~m}$ of the water column using a vertical

189 net with a mesh size $200 \mu \mathrm{m}$. SPM samples were collected with a Stand Alone Pump (SAP,

190 Challenger Oceanic ${ }^{\mathrm{TM}}$ ) mounted on a benthic lander that was deployed at $690 \mathrm{~m}$ depth, which

191 filtered a volume of $375 \mathrm{~L}$ on a GF/F filter. Two other samples (9 L each) were taken with a

192 CTD rosette sampler in the near-bottom water layer at 890 and $972 \mathrm{~m}$ depth and filtered over

193 pre-weighted and muffled GF/F filters. All fauna samples and filters were immediately stored

194 frozen $\left(-20^{\circ} \mathrm{C}\right)$.

In addition, between October 2011 and October 2012, a lander was deployed on

196 Galway Mound $\left(51^{\circ} 27.099 \mathrm{~N}, 11^{\circ} 45.135^{\prime} \mathrm{W}\right)$ at a depth of $786 \mathrm{~m}$. The lander was equipped with a near-bottom sediment trap (Technicap PPS4/3), fluorescence sensor (Wetlabs FLNTU) and HD video camera with infrared illumination (custom made at NIOZ). The content of the

199 sediment trap was preserved in situ with mercuric chloride. Individual sediment trap samples 
200 covered an exposure time of approximately one month and a total of 12 samples were

201 collected. The samples from the two deployments were analysed for bulk ${ }^{13} \mathrm{C}$ and ${ }^{15} \mathrm{~N}$

202 isotopes and chlorophyll $a$ content. The HD video camera took stills on a daily basis, which

203 were analysed for the number of visible aggregates per frame.

\section{Laboratory procedures}

205 Sediment trap samples were analysed for chlorophyll $a$ concentration by High Pressure

206 Liquid Chromatography as described in Duineveld et al. (2004). Faunal samples were sorted

207 and identified to the lowest possible taxonomic resolution. Tissue subsamples from

208 individual specimens were taken and analysed for $\delta^{13} \mathrm{C}, \delta^{15} \mathrm{~N}$ and fatty acid composition.

209 Subsamples (1-2 mg) for $\delta^{13} \mathrm{C}$ and $\delta^{15} \mathrm{~N}$ analysis were transferred to small silver boats,

210 acidified with $5 \% \mathrm{HCl}$ to remove inorganic carbon, oven-dried at $60^{\circ} \mathrm{C}$, pinched closed and

211 stored frozen before analysis on the Elemental Analyser (EA, Firma Thermo Electron, Flash

212 EA 1112 analyser) that was coupled to a Delta V isotope ratio mass spectrometer (IRMS) for

213 simultaneous measurement of ${ }^{13} \mathrm{C}:{ }^{12} \mathrm{C}$ and ${ }^{15} \mathrm{~N}:{ }^{14} \mathrm{~N}$ ratios. Reproducibility of the EA-IRMS

214 analysis was $0.25 \%$ for ${ }^{15} \mathrm{~N}$ and $0.2 \%$ for ${ }^{13} \mathrm{C}$. Samples were not lipid-extracted prior to

215 isotope analysis, as this is uncommon for deep-sea invertebrates and the low $\mathrm{C}: \mathrm{N}$ ratios of

216 these fauna implies that lipid-correction only marginally affects the results (Fanelli et al.

217 2011). Isotope values are expressed in the $\delta$-notation, which is the per mil (\%o) deviation of a

218 sample $\left(\mathrm{R}_{\text {sam }},{ }^{13} \mathrm{C}:{ }^{12} \mathrm{C}\right.$ for carbon and ${ }^{15} \mathrm{~N}:{ }^{14} \mathrm{~N}$ for nitrogen) relative to the isotope ratio of a

219 standard material $\left(\mathrm{R}_{\mathrm{STD}}\right.$ of carbon is $0.011180, \mathrm{R}_{\mathrm{STD}}$ of nitrogen is 0.003677$)$ as $\delta \mathrm{X}=\left(\mathrm{R}_{\text {sam- }}\right.$

$\left.220 / \mathrm{R}_{\mathrm{STD}}-1\right) \times 1000 \%$, with $\mathrm{X}$ representing ${ }^{13} \mathrm{C}$ or ${ }^{15} \mathrm{~N}$.

221 Total lipids were extracted from 10 to $60 \mathrm{mg}$ of wet fauna tissue or $5 \mathrm{~g}$ dry sediment

222 using a Bligh and Dyer extraction. The lipid extract was derivatised to volatile fatty acid

223 methyl esters (FAME) and measured for fatty acid concentration on a Gas Chromatograph 
224 coupled to a Flame Ionization Detector (GC-FID) or a Gas Chromatograph coupled to an

225 Isotope Ratio Mass Spectrometer (GC-IRMS) (Middelburg et al. 2000). Fatty acid (FA) data

226 are measured as $\mathrm{mg} \mathrm{FA} / \mathrm{g}$ wet weight, but since the interest in this paper is on the fatty acid

227 composition, the fatty acids are expressed as relative contribution to the total fatty acid pool.

228 This is done to normalize for differences in fatty acid concentrations that are due to different

229 body compositions, although hard body parts were removed from the animal tissues.

\section{$230 \quad$ Fatty acid biomarkers}

231 The use of fatty acids as individual biomarkers for the identification of food resources is not

232 unambiguous, because some fatty acids have been used as a 'unique' marker for different

233 food sources (Kelly \& Scheibling 2012). In this study, we therefore use only fatty acids as

234 specific markers that have been repeatedly used for one single food source and focus on their

235 relative abundance. The following fatty acid markers were considered bacteria-specific

236 iC14:0, iC15:0, aiC15:0, iC16:0, iC17:0, aiC17:0 and C18:107c (Alfaro et al. 2006;

237 Boschker \& Middelburg 2002; Brett et al. 2006; Howell et al. 2003; Meziane \& Tsuchiya

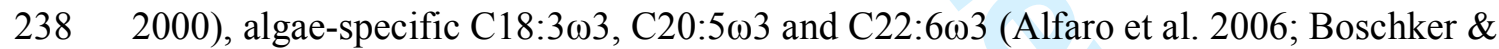

239 Middelburg 2002; Dijkman \& Kromkamp 2006; Ravet et al. 2010) and zooplankton-specific

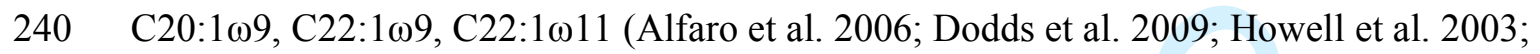

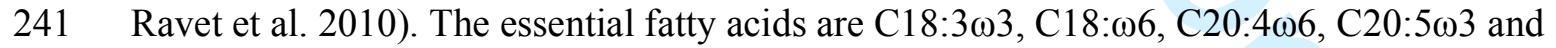

242 C22:6 63 (Arts et al. 2001). During the sampling at Træna we also obtained zooplankton

243 samples from the water column (see above), to compare the fatty acid profiles of these

244 samples against the selected 'zooplankton' markers found in other organisms.

\section{Multivariate statistics}

246 The summed proportional abundance of specific fatty acid markers of algae, bacteria and

247 zooplankton in reef fauna are analysed with principal component analysis (PCA) with either 
248 'site' or 'site + taxa' as grouping factor. When 'site' was used as a group factor, all samples

249 were included in the analysis, because this concerns the whole community. When 'site + 250 taxa' was used as group factor only taxa for which $n>1$ were included in the analysis. The

251 PCAs were performed on arcsine-transformed proportional abundances with the function 252 prcomp that is available in $\mathrm{R}$ ( $\mathrm{R}$ Development Core Team 2015). The prcomp function uses 253 singular value decomposition, which is a Euclidian-based method. The function ggbiplot 254 available in the R package ggplot2 (Wickham 2009) was used to plot the PCA results and to 255 add normal probability ellipsoids.

\section{Results}

\section{Trana deep coral reef field}

258 Stable isotope samples from the Træna area are partitioned over 5 organic matter sources, 14

259 reef fauna groups and 10 fish species (Fig. 2A, Table 1). The $\delta^{13} \mathrm{C}$ values range from $-26.9 \%$ o

260 (SPM) to $-17.0 \%$ (sea star Henricia pertusa) and $\delta^{15} \mathrm{~N}$ values range from $5.4 \%$ (small

261 Calanus sp.) to $16.6 \%$ (H. pertusa). The $\delta^{15} \mathrm{~N}$ isotope values of the on- and off-reef sediment, 262 suspended organic matter, small and large Calanus copepods are all lower than those of the

263 reef fauna (Fig. 2A). The associated reef fauna has a $\delta^{13} \mathrm{C}$ range of $-24.5 \%$ (Lophelia 264 pertusa) to $-17.0 \%$ (H. pertusa) and a $\delta^{15} \mathrm{~N}$ range of $8.2 \%$ (Lophelia pertusa) to $16.6 \%$ ( $H$.

265 pertusa). The mean isotope value of sponges is relatively high $\left(\delta^{13} \mathrm{C}=-18.2 \%\right.$, $\delta^{15} \mathrm{~N}=$ $26615.6 \%$ ) and has a large standard deviation. The range of $\delta^{13} \mathrm{C}$ values of the fishes $(-22.3 \%$ to

$267-18.1 \%$ ) is comparable to that of the reef fauna, but $\delta^{15} \mathrm{~N}$ values tend to be higher and range

268 from 10.3\% to 13.6\%. The euphausiids Meganyctiphanes norvegica and Thysanoessa

269 inermis have slightly lower $\delta^{15} \mathrm{~N}$ values (9.4 and 8.8\%o, respectively) as the reef-associated

270 fauna. The sea cucumber Parastichopus tremulus and the ophiuroid Ophiopholis aculeata

271 also have comparatively low $\delta^{15} \mathrm{~N}$ values (9.8 and 10.3\%o, respectively). Within the 
272 crustaceans, the squat lobster Munida rugosa has lowest $\delta^{15} \mathrm{~N}$ value (10.4\%o), followed by the 273 shrimp Pandalus borealis (11.9\%o) and finally the king crab Lithodes maja (12.1\%o). Fish

274 have $\delta^{15} \mathrm{~N}$ values ranging from $10.3 \%$ for the Norway pout (Trisopterus esmarkii) to $13.6 \%$

275 for tusk (Brosme brosme), which is generally higher as compared to the other reef fauna.

276 The concentration of total fatty acids $\left(\mathrm{mg} \mathrm{C} \mathrm{g}^{-1} \mathrm{WW}\right)$ for CWC reef fauna at Træna is

277 variable, but lower than 5\% of the wet weight for all organisms, except for the pearlside

278 Maurolicus muelleri (7.5\%) (Table 3). Other species with a comparatively high fraction of

279 fatty acids are krill Thysanoessa inermis (4.9\%), fish Pollachius virens (1.6\%) and both

280 zooplankton size classes $(2.9 \%$ and $5 \%)$. Sediments have lowest $(<0.015 \%)$ fatty acid

281 fractions, while the holothurian Parastichopus tremulus and the crustacean Lithodes maja

282 have the lowest fatty acid concentrations among the fauna $(<0.06 \%)$. No fatty acid data are

283 available for SPM, because the whole filter had to be used for analysis of bulk $\delta^{13} \mathrm{C}$ and $\delta^{15} \mathrm{~N}$.

284 Bacterial fatty acids are found in all CWC fauna, but the percentage of summed

285 bacterial fatty acids ranges from 1 to almost 20\% (Fig. 3A). Sediments, sponges,

286 echinoderms and crustaceans have a higher contribution of bacterial fatty acids ( $>7$ to $20 \%$ )

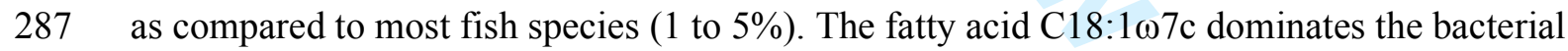

288 markers and generally represents $>2 \%$ of the total fatty acids, while other bacterial markers

289 typically represent $<1 \%$ (Table 3 ). The branched short-chained bacterial fatty acid iC14:0 is

290 not detected in many CWC fauna, especially the fish species, but represents $0.7-0.9 \%$ of the

291 total fatty acid pool in sediments.

292 Summed algal fatty acids contribute up to $45 \%$ of the total fatty acids for the fish

293 species Chimaera monstrosa (Rabbit fish), Hippoglossoides platessoides (American plaice)

294 and Trisopterus esmarkii (Norway pout) (Fig. 3B). Fish species, except for Brosme brosme

295 and Pollachius virens, have a high algal fatty acid contribution of $>32 \%$, as well as Sepiola 
atlantica, crustaceans, euphausiids and both Calanus size classes. Low algal fatty acid

297 contributions (generally $<10 \%$ ) are found for Lophelia pertusa, echinoderms, sponges and

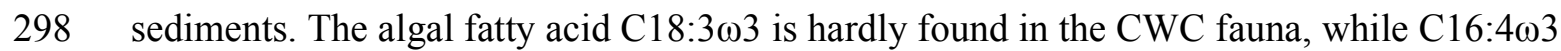

299 and $\mathrm{C} 18: 4 \omega 3$ generally represent $<1 \%$ of the total fatty acids (Table 3 ). A notable exception

300 is the high $(\sim 10 \%) \mathrm{C} 18: 4 \omega 3$ content of both Calanus size classes. Though variable, the algal

301 markers $\mathrm{C} 20: 5 \omega 3$ and $\mathrm{C} 22: 6 \omega 3$ generally dominate the fatty acids of reef fauna.

Lophelia pertusa and Brosme brosme (Fig. 3C). The fatty acid C20:1 $19 \mathrm{c}$ is found in most

304 CWC fauna and dominates the specific zooplankton fatty acids $(0.5-3 \%)$. The fatty acid

$305 \mathrm{C} 22: 1 \omega 11$ has the lowest contribution (generally $<0.5 \%$ ), but is found in more fauna than

$306 \mathrm{C} 22: 1 \omega 9$, although when present, the latter fatty acid contributes between 1 to $3 \%$ of the total

307 fatty acid pool.

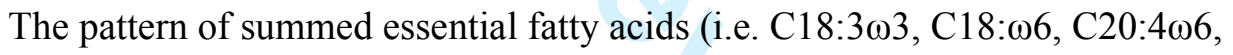

$309 \mathrm{C} 20: 5 \omega 3$ and $\mathrm{C} 22: 6 \omega 3)$ resembles that of algal fatty acids, since the dominant fatty acids

$310 \mathrm{C} 18: 3 \omega 3, \mathrm{C} 20: 5 \omega 3$ and $\mathrm{C} 22: 6 \omega 3$ overlap between the two fatty acid sets (Fig. 3B, D).

311 However, the contribution of the fatty acid C20:4

312 and Henricia pertusa, which raises their total essential fatty acid content substantially (Fig.

313 3D, Table 3).

\section{Belgica Mounds}

315 Stable isotope samples from Belgica Mounds are partitioned over 33 biotic compartments,

316 including scleractinian and soft corals, sponges, sea stars and 7 fish species (Fig. 2B, Table

317 2). Zooplankton has mean bulk $\delta^{13} \mathrm{C}$ and $\delta^{15} \mathrm{~N}$ values of $-20.6 \%$ and $3.5 \%$, respectively. The

318 large volume SPM sample taken with the SAPS pump and the two SPM samples from the

319 CTD-rosette were comparable and have a mean bulk $\delta^{13} \mathrm{C}$ of $-25.7 \%$ and $\delta^{15} \mathrm{~N}$ value of 
$3205.4 \%$. Sediment trap samples are slightly higher than the SPM samples and have a mean $\delta^{13} \mathrm{C}$

321 of $-22.30 \%$ and a mean $\delta^{15} \mathrm{~N}$ of $7.0 \%$. Bulk $\delta^{13} \mathrm{C}$ values of the cold-water coral community

322 of the Belgica Mounds range from -22.1\%o (Ophiuroidea spp.) to -12.2\%o (Asteroidea spp.)

323 and bulk $\delta^{15} \mathrm{~N}$ isotope values range from 6.8\% (Lepidion eques) to 19.6\% (Aphrocallistes

324 sp.) (Fig. 2B). The isotope values of most species range between $-22 \%$ to $-16 \%$ for $\delta^{13} \mathrm{C}$ and

$3257 \%$ to $13 \%$ for $\delta^{15} \mathrm{~N}$ (Fig. 2B). Lophelia pertusa $\left(\delta^{13} \mathrm{C}-18.4 \%\right.$ and $\delta^{15} \mathrm{~N} 7.6 \%$ ) grouped

326 closely with other cnidarians such as Cirrhipathes sp. $\left(\delta^{13} \mathrm{C}-18.4 \%\right.$ and $\delta^{15} \mathrm{~N} 7.3 \%$ ) and

327 Madrepora oculata $\left(\delta^{13} \mathrm{C}-18.4 \%\right.$ and $\delta^{15} \mathrm{~N} 7.3 \%$ ). The sponges Spongosorites $\mathrm{sp} .\left(\delta^{13} \mathrm{C}-\right.$

$328 \quad 17.3 \%$ and $\delta^{15} \mathrm{~N} 7.3 \%$ ), Hexactinellida sp. $\left(\delta^{13} \mathrm{C}-20.0 \%\right.$ and $\delta^{15} \mathrm{~N} 12.8 \%$ ) and Aphrocallista

329 sp. $\left(\delta^{13} \mathrm{C}-17.9 \%\right.$ and $\delta^{15} \mathrm{~N} 19.6 \%$ ) have a large variability in their bulk isotope values. Fish

330 species, other than Lepidion eques, are not separated by large differences in the $\delta^{13} \mathrm{C}$ (range: -

33116.5 to $-18.6 \%$ ) and $\delta^{15} \mathrm{~N}$ values (range: 9.1 to $11.8 \%$ ).

332 The total concentration of fatty acids $\left(\mathrm{mg} \mathrm{C} \mathrm{g}^{-1} \mathrm{WW}\right)$ is highly variable among the

333 reef fauna at Belgica Mounds, but tends to be $\leq 1 \%$ of the wet weight except for the fish

334 species Epigonus telescopus (Black cardinal fish) and the crustacean Cirripedia spp. (Table

335 4). Lowest fatty acid concentrations are found for the two sponge taxa Aphrocalliste sp. and

336 Hexactinellida sp. The total fatty acid concentration of SPM was $10 \mu \mathrm{g} \mathrm{C} \mathrm{L}^{-1}$.

The summed contribution of bacterial fatty acids is $>1 \%$ and $<6 \%$ for most CWC reef

338 fauna at Belgica Mounds (Fig. 4A), except for Amphipoda (24\%) and the two sponge taxa

339 Hexactinellida sp. (8.6\%) and Spongosorites sp. (12\%). Short-chained and branched fatty

340 acids, especially iC $14: 0$, are not found in all fauna and contribute generally $<1 \%$ to the total

341 fatty acid pool. A notable exception is that the bacterial fatty acid iC17:0 occurs in

342 appreciable levels in almost all Cnidaria, in particular in Lophelia pertusa and Madrepora

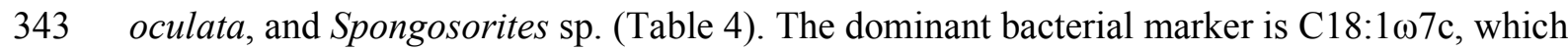


contributes $1 \%$ to $6 \%$ of the total fatty acid pool.

The contribution of summed algal fatty acids ranges from $1 \%$ (Asteroidea spp.) to

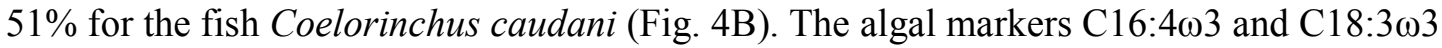

are absent in nearly all reef fauna, with the notable exception of the high $\mathrm{C} 16: 4 \omega 3$ percentage

in Lophelia pertusa (2.6\%) and SPM (2.3\%) (Table 4). The contribution of the fatty acid

C20:5 03 differs considerably among species with values $<3 \%$ for Spongosorites sp., Salpidae

sp. and the echinoderms Asteroidea spp. and Cidaris sp., but $>17 \%$ for Cirrhipathes sp.

(Spiral wire coral), the octopus Bathypolypus bairdii and the polychaete Eunice norvegica.

The fatty acid C22:613 generally dominates the algal markers, but is particularly high in echinoderms, molluscs and most fish species with contributions of 10 to $40 \%$.

Zooplankton markers are low in abundance (generally $<2 \%$ ) (Fig. 4C). Two of the

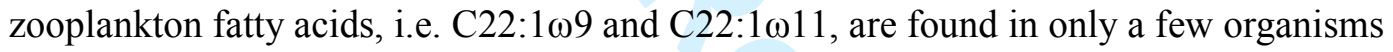
(Table 4), although a high C22:1w11 content of $\geq 2 \%$ is detected in the CWC Lophelia pertusa and Madrepora oculata. The fatty acid C20:169c is found in nearly all samples and in a high content in Echinus sp. and Asteroidea spp. and two cnidarians Anthomastus sp. and Cirrhipathes sp.

The summed essential fatty acids contribute substantially to the total fatty acid pool of the reef fauna, with most contributions $>20 \%$ (Fig. 4D). Essential fatty acids seem to concentrate in fish, where the contribution is $>30 \%$, except for Neocyttus helgae (20\%) (Fig. 4D).

The mooring-mounted fluorescence sensor shows a comparatively low fluorescence signal throughout the year (Fig. 5A), while chlorophyll $a$ deposition in the sediment trap increases from undetectable quantities in winter to $0.14 \mathrm{ng} \mathrm{m}^{-2} \mathrm{~d}^{-1}$ in May. Following this 
368 the year (Fig. 5B). Aggregates, as countable on the HD video camera stills, are largely absent

369 in the winter months (Fig. 5C, left inset), but aggregate density increases markedly from

370 March to May (Fig. 5C, right inset) with peak values of $>40$ visible aggregates per still

371 image. The abundance of aggregates on the still images decreases again towards July and

372 August.

\section{Multivariate analyses of fatty acid compositions}

374 The PC1 and PC2 of the PCA of the summed specific algal, bacterial and zooplankton fatty

375 acids explain a total of $84.9 \%$ of the variance, respectively (Fig. 6). The first axis relates to

376 increasing bacterial relative to algal markers, while the second axis discriminates the

377 abundance of zooplankton markers. The Belgica Mound samples were primarily separated on

378 the PC1 axis. Most Belgica Mound samples did not separate strongly and the normal

379 probability ellipsoid is centred on the summed algal fatty acids. The PCA separates the Træna

380 samples primarily on the PC1 axis by algal and bacteria fatty acids and to a lesser extent on

381 the PC2 axis by zooplankton fatty acids (Fig. 6). The samples from Træna however, were

382 more diverse than the samples from Belgica Mounds, resulting in a broader normal

383 probability ellipsoid as compared to Belgica Mounds.

384 The PC1 and PC1 axes of the PCA plot of Cnidarians explain a total of $85 \%$ of the

385 variance (Fig. 7A). The Cnidarian samples from Træna consist exclusively of Lophelia

386 pertusa and are separated from the Belgica Mounds samples, because of the higher

387 zooplankton fatty acid contribution in their tissue (Fig. 7A). The PCA performed on the

388 Cnidarian species (Fig. 7B) shows that species from Belgica Mounds typically have more

389 specific algal (e.g. Cirrhipathes sp.) or bacterial (e.g. Gorgonian spp.) fatty acids in their

390 tissues as compared Cnidarians from Træna. The PCA of all fish samples, with PC1 and PC2

391 together explaining a total of $92.5 \%$ of the variance, shows that the fish samples from Belgica 
392 Mounds closely cluster together at the variable denoting high algal contributions (Fig. 7C). In

393 contrast, the fish samples from Træna are separated by all three variables, resulting in a broad

394 normal probability ellipsoid. Separate fish species at Træna however have narrow isotopic

395 ellipsoids, so that the broad overall composition is clearly related to different species, each

396 with specific compositions. For instance, Brosme brosme is characterised by a high

397 contribution of zooplankton fatty acids, while Sebastes viviparus has a high contribution of

398 algal fatty acids (Fig. 7D).

\section{Discussion}

\section{The trophic base of cold-water coral reef communities}

401 Our results indicate that the trophic base of reefs of Træna and in particular of Belgica

402 Mounds is strongly dominated by algae, or more likely, phytodetritus. The fatty acid

403 C22:6 63 was used as marker for feeding on fresh phytodetritus by abyssal copepods by

404 Bühring \& Christiansen (2001). The percentage of C22:6 $\omega 3$ in the reef fauna of Træna and

405 Belgica Mounds was similar to the abyssal copepods, suggesting a dependence on relatively

406 fresh phytodetritus. Thiem et al. (2006) suggested that the transport of fresh phytodetritus to

407 Norwegian reefs is maintained by high primary production on the shelf and along the shelf

408 break that is subsequently transported to the seafloor with the aid of 1) eddies and small

409 fronts that are generated by the bottom topography and 2) a semi-permanent front between

410 the North Atlantic Water and the Norwegian Coastal Current that generates local down-

411 welling. In contrast, the interaction of tidal flows with bottom topography is likely important

412 for the transport of fresh phytodetritus to the Belgica Mounds. Mohn et al. (2014) applied a

413 hydrodynamic model to this region and found that an oscillatory tidal flow interacting with

414 the mound topography promotes the transport of fresh phytodetritus to Belgica Mound reefs.

415 Interestingly, the fluorescence signal at Belgica Mounds is low throughout the year, which 
416 seemingly contradicts the dependence of reef fauna on fresh phytodetritus. In apparent

417 contradiction, the chlorophyll $a$ deposition flux is higher in April to June, which indicates an

418 input of fresh phytodetritus in spring. The observed aggregate abundance is mirrored in the

419 chlorophyll $a$ deposition flux and we therefore suggest that fresh phytodetritus arrives as

420 aggregates that are not detected by the fluorescence sensor. Likely, the detection volume of

421 the fluorescence sensor is too small to reliably sense the aggregates.

The relative contribution of algal fatty acids in reef fauna provides information on the dominant primary producer supporting the food web. The algal marker $\mathrm{C} 20: 5 \omega 3$ is a diatom marker, while C22:613 is specific for dinoflagellates (Dijkman \& Kromkamp 2006; Kelly \& Scheibling 2012). The ratio of these fatty acids signifies their relative importance as primary resource, in which a $\mathrm{C} 20: 5 \omega 3 / \mathrm{C} 22: 6 \omega 3$ ratio of $>1$ is diatom-dominated and a ratio of $<1$ is dinoflagellate-dominated (Alfaro et al. 2006; Budge \& Parrish 1998; Dalsgaard et al. 2003). The $\mathrm{C} 20: 5 \omega 3 / \mathrm{C} 22: 6 \omega 3$ ratio is predominantly $<1$ in reef fauna from both Træna and Belgica Mounds, indicating a dinoflagellate dominance at the base of the food web. Dinoflagellates dominate over diatom abundance along the Norwegian shelf (Slagstad et al. 1999) and this

431 dominance has increased in the last two decades (Edwards et al. 2006). In the Atlantic Ocean and along the Irish coast, dinoflagellates and diatoms dominate the phytoplankton community

433 (Painter et al. 2010; Raine et al. 2002), but dinoflagellates may outcompete diatoms (Henson et al. 2012). Evidently, the dinoflagellate dominance in the upper water column is transferred to both reef systems. to Belgica Mounds. The $\delta^{15} \mathrm{~N}$ and $\delta^{13} \mathrm{C}$ values of Lophelia pertusa, when using fractionation values of $2-4 \%$ for $\delta^{15} \mathrm{~N}$ and $0-1 \%$ for $\delta^{13} \mathrm{C}$ that are typical for deep-sea stable isotope studies (Fanelli et al. 2011; Iken et al. 2001; Petursdottir et al. 2008), suggest that Calanus 
440 copepods are an important resource at the Træna reef. The importance of Calanus copepods

441 is confirmed from the relatively high fraction of zooplankton markers in L. pertusa. It is 442 important to note that Mueller et al. (2014) showed de novo synthesis of the 'zooplankton' 443 fatty acid $\mathrm{C} 20: 1 \omega 9 \mathrm{c}$ in a physiological study with stable isotopes. This cautions against the 444 use of 'only' zooplankton markers to determine the importance of copepods in diets of cold445 water corals without sampling zooplankton directly and stable isotope analysis. The $\delta^{13} \mathrm{C}$ and $446 \quad \delta^{15} \mathrm{~N}$ values of other reef fauna are too high as compared to Calanus copepods to suggest that 447 the latter contributes significantly to their nutrition. Most reef fauna mirrors the fatty acid 448 profile of the euphausiid species Meganyctiphanes norvegica and Thysamoessa intermis that 449 were caught near the reefs. These euphausiids are the dominant krill species on the 450 Norwegian Shelf (Dalpadado 2006) and are apparently an important resource for the reef 451 food web. Indeed, the lights of the Campod videocamera had to be shut off regularly during 452 surveys of the Træna reefs, because the view was blocked by swarms of euphausiids (T. 453 Kutti, pers. obs.).

At Belgica Mounds, zooplankton $\delta^{15} \mathrm{~N}$ isotope values are $>4 \%$ lower than the reef fauna, suggesting a limited importance of zooplankton for the food web. Other lines of evidence support this. Images from the moored-camera show no visible zooplankton around the reefs, sediment trap deployments repeatedly show no or very low numbers of 'zooplankton swimmers' on the filters (G. Duineveld, pers. obs.) and concentrations of

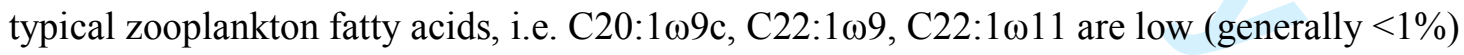

460 in most reef fauna. A notable exception to this latter argument are cnidarians, including 461 Lophelia pertusa, which have a comparatively high C20:1 $19 \mathrm{c}$ content as compared to the other reef fauna. As mentioned above, this does not necessarily indicates feeding on 463 zooplankton, because L. pertusa may synthesize this fatty acid. The depth of the reefs at 464 Belgica Mounds probably implies that they are outside the zooplankton migration window, 
465 which causes zooplankton to be of low importance to the reef food web.

466 The proportion of bacterial markers in most reef-associated fauna was low, especially

467 when compared to those deep-sea systems that are primarily supported by bacterial

468 symbionts (Ben-Mlih et al. 1992; Colaço et al. 2007; Phleger et al. 2005). Two pathways may

469 explain how bacterial production would contribute to the diets of a reef community. The

470 'hydraulic theory' hypothesizes that coral reef communities are supported by seafloor

471 seepage of reduced chemical species (e.g. $\mathrm{H}_{2} \mathrm{~S}$ and methane), which provide energy for

472 pelagic or symbiotic microbes that in turn supports reef communities (Hovland et al. 2012).

473 Alternatively, mucus released by cold-water corals and subsequent stimulation of bacterial

474 production in reef water (Wild et al. 2008) could elevate the importance of bacterial carbon

475 for the reef community. Chemosynthetic support of a food web can be identified from

476 depleted faunal $\delta^{13} \mathrm{C}$ and $\delta^{15} \mathrm{~N}$ values, but isotope values from both reefs are too high for a

477 possible chemosynthetic basis of the food web (Van Gaever et al. 2006). The low

478 contribution of bacterial fatty acids indicates that support by pelagic bacterial production is

479 less important than that of phytodetritus and zooplankton, especially for fish. A notable

480 exception here are benthic crustaceans and echinoderms. Here bacterial contributions may be

481 elevated through feeding on sedimentary detritus, which is rich in bacterial fatty acids.

\section{Pathways within the coral-reef food webs}

483 A high variability was observed in the $\delta^{15} \mathrm{~N}$ and $\delta^{13} \mathrm{C}$ values of sponges at Træna and Belgica

484 Mounds (Fig. 2, 8), but also at other deep-sea locations (Duineveld et al. 2007; Iken et al.

485 2001). Sponges are holobionts, hosting a diverse community of microbial symbionts in their

486 tissue that may represent up to $35 \%$ of the total sponge biomass (Weisz et al. 2008). The

487 deep-water sponges at Træna and Belgica Mounds have among the highest contributions of

488 bacterial fatty acids of all fauna, suggesting that they have abundant associated microbes. 
489 Deep-water sponges are known to efficiently retain bacterioplankton (Yahel et al. 2007) and

490 take up dissolved organic carbon (van Duyl et al. 2008). However, deep-water sponges are

491 also capable of nitrification, denitrification, annamox and nitrogen fixation (Hoffmann et al.

492 2009), which are microbial-mediated metabolic pathways that will draw $\delta^{15} \mathrm{~N}$ and $\delta^{13} \mathrm{C}$ values

493 of sponge tissue away from values that are typical for heterotrophic feeding on suspended

494 particulate or dissolved matter. From our results, we cannot identify which metabolic

495 processes are active, but the large variability in $\delta^{15} \mathrm{~N}$ and $\delta^{13} \mathrm{C}$ values of individual sponges

496 suggests a high diversity in carbon and nitrogen (re)cycling pathways. A complex carbon and

497 nitrogen cycling combined with the dominance of sponges at many cold-water coral reefs

498 (Van Soest \& Lavaleye 2005) and their high filtration capacity (Kutti et al. 2013; Yahel et al.

499 2007) suggests that sponges may significantly influence the biogeochemistry of the reef

500 water. Furthermore, deep-sea sponges take up coral-derived DOM and make this available to

501 higher trophic levels by transforming it into particulate detritus (Rix et al. 2016).

502 The range in $\delta^{15} \mathrm{~N}$ values for fauna at both reefs is restricted to $\sim 5 \%$ at Træna and

$503 \sim 7 \%$ at Belgica Mounds. This $\delta^{15} \mathrm{~N}$ range indicates that organisms differ by only 1.5 to 2.5

504 trophic steps in both food webs (assuming a $\delta^{15} \mathrm{~N}$ trophic fractionation factor of $3 \%$ ). It is

505 important to note that large predatory fish are not included in our study, but a relatively flat

506 food web is consistent with reports from Rockall Bank in the eastern Atlantic (Duineveld et

507 al. 2007), Santa Leuca di Maria in the Mediterranean Sea (Carlier et al. 2009) and western

508 Atlantic reefs off the coast of Canada (Sherwood et al. 2008).

509 Deposit and suspension feeders occupy the lowest trophic level at both locations,

510 including cold-water corals and other cnidarians, stalked barnacles, holothurians and

511 suspension-feeding ophiuroids. At Belgica Mounds however, several deposit or suspension

512 feeders such as hydroids, the bivalve Hiatella arctica and holothurians have a comparatively

513 high $\delta^{15} \mathrm{~N}$ value. While this may indicate feeding at a higher trophic level, it is more likely 
514 that these species exploit more refractory organic matter and associated bacteria that

515 temporarily resuspends from the seafloor (Davies et al. 2009; Iken et al. 2001). Similarly,

516 benthic crustaceans have high $\delta^{15} \mathrm{~N}$ values, a comparatively high percentage of bacterial fatty

517 acids and a lower fraction of algal fatty acids, which indicates detritus feeding in both reef

518 food webs.

519 The sea urchin Cidaris sp. and sea stars (Asteroidea spp.) have among the highest

$520 \delta^{15} \mathrm{~N}$ values at both reefs. This is consistent with other cold-water coral reefs, where a snow

521 crab (Canada, Sherwood et al. 2008), sea star (Mediterranean, Carlier et al. 2009) and sea

522 urchin (Irish margin, Duineveld et al. 2007) had highest $\delta^{15} \mathrm{~N}$. These species are mobile

523 predators with a broad diet spectrum including sponges, polychaetes and bivalves and the

524 high $\delta^{15} \mathrm{~N}$ values is therefore related to its high trophic position in the food web (Emson \&

525 Young 1994; McClintock 1994; Wieczorek \& Hooper 1995). Stevenson and Rocha (2013)

526 documented that four sea urchin species actively predate on living Lophelia pertusa and

527 Madrepora oculata. The $\delta^{15} \mathrm{~N}$ difference between echinoids and cold-water corals is however

$528>4 \%$, indicating that corallivory is not the main feeding mode of echinoderms.

529 Fish species at Træna included several (commercially relevant) demersal and pelagic

530 species. The pelagic species Maurolicus muelleri, Pollachius virens and Sebastes viviparus

531 often have a diet consisting of Calanus copepods, euphausiids and fish (Bundy et al. 2011;

532 Carruthers et al. 2005; Husebø et al. 2002; Jaworski \& Ragnarsson 2006; Petursdottir et al.

533 2008). The $6.5 \%$ difference in $\delta^{15} \mathrm{~N}$ between Calanus copepods and M. muelleri is too large

534 for Calanus to be their main prey item. Instead, euphausiids are likely more important based

535 on the $\delta^{15} \mathrm{~N}$ values and the high abundance of the algal fatty acid marker C20:5 13 in both

536 euphausiids and M. muelleri. Pollachius virens often occurs in high abundance near the cold-

537 water coral reefs (Husebø et al. 2002; Kutti et al. 2015) and euphausiids are often an

538 important prey item (Carruthers et al. 2005; Jaworski \& Ragnarsson 2006). The 3\%o 
539 difference between the $\delta^{15} \mathrm{~N}$ value of $P$. virens and euphausiids is consistent with feeding on

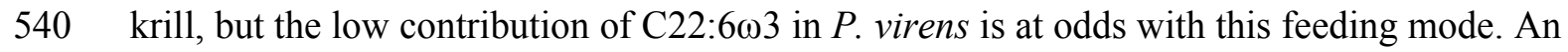

541 alternative diet may involve feeding on fish from soft-bottom sediments such as Ammodytes

542 sp. (Sand lance) (Carruthers et al. 2005). Stomach content studies of S. viviparus indicated

543 that Calanus copepods are a main diet component (Bundy et al. 2011). At Træna, we could

544 analyse only one specimen for $\delta^{15} \mathrm{~N}$, but the $7 \%$ difference in $\delta^{15} \mathrm{~N}$ indicates that Calanus sp.

545 are not their main diet. Husebø et al. (2002) found that reef-associated S. viviparus had more

546 predatory copepods (Euchaeta spp.) in their stomach, which may explain the high $\delta^{15} \mathrm{~N}$ of $S$.

547 viviparus reported here. Stomach content studies of demersal fish species that were sampled

548 here, e.g. Chimaera monstrosa, Brosme brosme and Phycis blennoides, often have a diverse

549 diet of benthic fauna including polychaetes, small amphipods and squat lobster (Munida sp.)

550 (Bergstad et al. 2003). Our isotope and fatty acid data do not allow identifying a dominant

551 food source from such a wide spectrum, but $\delta^{15} \mathrm{~N}$ values of demersal species are elevated as

552 compared to pelagic species (e.g. Trisopterus esmarkii) and so their feeding is probably

553 linked to secondary production of the reef-associated fauna community. The high biomass of

554 reef fauna may therefore explain the high abundance of demersal fish species at Træna (Kutti

555 et al. 2015).

556 Fish sampled at Belgica Mounds are mostly non-commercial demersal species, of

557 which Lepidion eques and Guttigadus latifrons are associated with the coral framework

558 (Biber et al. 2014; Soffker et al. 2011). Lepidion eques occurs on both slope sediments and

559 cold-water coral reefs (Biber et al. 2014; Soffker et al. 2011), but the low $\delta^{15} \mathrm{~N}$ value of $L$.

560 eques is at odds with their suspected feeding on epi-and hyperbenthic crustaceans (Mauchline

$561 \&$ Gordon 1980). Limited diet information is available for the non-commercial demersal

562 species Cataetyx alleni, Coelorinchus caudani, Gaidropsarus vulgaris and G. latifrons, but

563 they seem to feed opportunistically on benthic and epibenthic prey including polychaetes, 
564 shrimps, amphipods, crabs and small fish (Blaber \& Bulman 1987; Carrasson \& Cartes

565 2002). Indeed, the elevated $\delta^{15} \mathrm{~N}$ value and fatty acid composition (i.e. dominance of

$566 \mathrm{C} 22: 6 \omega 3$, low contribution of $\mathrm{C} 20: 4 \omega 6$ and $\mathrm{C} 20: 5 \omega 3$, and a near absence of zooplankton

567 fatty acids) indicates feeding on crustaceans from the coral reef food web. Algal and essential

568 fatty acids are highest in the fish from Belgica Mounds and as these fatty acids are retained in

569 pelagic food webs (Kainz et al. 2004), we infer that benthic fauna form a trophic link to the

570 demersal fish at Belgica Mounds.

In conclusion, we show differences in the trophic structure of two cold-water coral

572 reefs that contrast in their environmental setting. Phytodetritus is at the base of both coral-

573 reef food webs, but we speculate that the mechanism that drives the coupling of the reef food

574 web with surface productivity differs between locations and depends on the hydrography.

575 The resource spectrum that was utilised by the food web at Træna was much broader than at

576 Belgica Mounds, as Calanus copepods and euphausiids likely migrate to the depths of the

577 reefs and provide a conduit for the transfer of phytoplankton to the reef food web and

578 associated pelagic fish. The coral reefs at Belgica Mounds are several hundreds of meters

579 deeper than Træna and lack this zooplankton contribution. Instead, the reef food web at

580 Belgica Mounds is primarily supported by phytodetritus, which is transferred to demersal fish

581 that feed on benthic fauna of the reef food web. 
582

583

584

585

586

587

588

589

590

591

592

593

594

595

596

597

598

599

600

601

602

603

604

605

606

607

608

609

610

611

612

613

\section{References}

Alfaro AC, Thomas F, Sergent L, Duxbury M. 2006. Identification of trophic interactions within an estuarine food web (northern New Zealand) using fatty acid biomarkers and stable isotopes. Estuarine Coastal and Shelf Science 70:271-286.

Angel MV, de C. Baker A. 1982. Vertical distribution of the standing crop of plankton and micronekton at three stations in the Northeast Atlantic. Biological Oceanography 2:130.

Arts MT, Ackman RG, Holub BJ. 2001. "Essential fatty acids" in aquatic ecosystems: a crucial link between diet and human health and evolution. Canadian Journal of Fisheries and Aquatic Sciences 58:122-137.

Auster PJ, 2005. Are deep-water corals important habitats for fishes? In: Freiwald A, Roberts JM, editors. Cold-Water Corals and Ecosystems. Berlin: Springer-Verlag, p 747-760.

Ben-Mlih F, Marty JC, Fialamedioni A. 1992. Fatty-acid composition in deep hydrothermal vent symbiotic bivalves. Journal of Lipid Research 33:1797-1806.

Bergstad OA, Wik AD, Hildre O. 2003. Predator-prey relationships and food sources of the Skagerrak deep-water fish assemblage. Journal of Northwest Atlantic Fishery Science 31:165-180.

Biber MF, Duineveld GCA, Lavaleye MSS, Davies AJ, Bergman MJN, van den Beld IMJ. 2014. Investigating the association of fish abundance and biomass with cold-water corals in the deep Northeast Atlantic Ocean using a generalised linear modelling approach. Deep-Sea Research Part II -Topical Studies in Oceanography 99:134-145.

Blaber SJM, Bulman CM. 1987. Diets of fishes of the upper continental-slope of eastern Tasmania: content, calorific values, dietary overlap and trophic relationships. Marine Biology 95:345-356.

Boschker HTS, Middelburg JJ. 2002. Stable isotopes and biomarkers in microbial ecology. FEMS Microbiology Ecology 40:85-95.

Brett MT, Muller-Navarra DC, Ballantyne AP, Ravet JL, Goldman CR. 2006. Daphnia fatty acid composition reflects that of their diet. Limnology and Oceanography 51:24282437.

Budge SM, Parrish CC. 1998. Lipid biogeochemistry of plankton, settling matter and sediments in Trinity Bay, Newfoundland. II. Fatty acids. Organic Geochemistry 29:1547-1559. 
614 Bühring SI, Christiansen B. 2001. Lipids in selected abyssal benthopelagic animals: links to 615 the epipelagic zone? Progress in Oceanography 50:369-382.

616 Bundy A, Link JS, Smith BE, Cook AM. 2011. You are what you eat, whenever or wherever 617 you eat it: an integrative analysis of fish food habits in Canadian and U.S.A. waters. 618 Journal of Fish Biology 78:514-539.

619 Carlier A, Le Guilloux E, Olu K, Sarrazin J, Mastrototaro F, Taviani M, et al. 2009. Trophic 620 relationships in a deep Mediterranean cold-water coral bank (Santa Maria di Leuca, 621 Ionian Sea). Marine Ecology Progress Series 397:125-137.

622 Carrasson M, Cartes JE. 2002. Trophic relationships in a Mediterranean deep-sea fish 623 community: partition of food resources, dietary overlap and connections within the 624 benthic boundary layer. Marine Ecology Progress Series 241:41-55.

625 Carruthers EH, Neilson JD, Waters C, Perley P. 2005. Long-term changes in the feeding of 626 Pollachius virens on the Scotian Shelf: responses to a dynamic ecosystem. Journal of $627 \quad$ Fish Biology 66:327-347.

628 Colaço A, Desbruyeres D, Guezennec J. 2007. Polar lipid fatty acids as indicators of trophic 629 associations in a deep-sea vent system community. Marine Ecology-an Evolutionary $630 \quad$ Perspective 28:15-24.

631 Costello MJ, McCrea M, Freiwald A, Lundälv T, Jonsson L, Bett BJ, et al., 2005. Role of 632 cold-water Lophelia pertusa coral reefs as fish habitat in the NE Atlantic. In: Freiwald 633 A, Roberts JM, editors. Cold-Water Corals and Ecosystems. Berlin: Springer-Verlag, $p$ $634771-805$.

635 D'Onghia G, Maiorano P, Sion L, Giove A, Capezzuto F, Carlucci R, et al. 2010. Effects of 636 deep-water coral banks on the abundance and size structure of the megafauna in the 637 Mediterranean Sea. Deep-Sea Research Part II-Topical Studies in Oceanography $638 \quad 57: 397-411$.

639 Dalpadado P. 2006. Distribution and reproduction strategies of krill (Euphausiacea) on the $640 \quad$ Norwegian shelf. Polar Biology 29:849-859.

641 Dalsgaard J, St. John M, Kattner G, Müller-Navarra D, Hagen W. 2003. Fatty acid trophic 642 markers in the pelagic marine environment. Advances in Marine Biology 46:225-340. 643 Davies AJ, Duineveld GCA, Lavaleye MSS, Bergman MJN, Van Haren H, Roberts JM. 644 2009. Downwelling and deep-water bottom currents as food supply mechanisms to the 645 cold-water coral Lophelia pertusa (Scleractinia) at the Mingulay Reef complex. 646 Limnology and Oceanography 54:620-629. 
Dijkman NA, Kromkamp JC. 2006. Phospholipid-derived fatty acids as chemotaxonomic markers for phytoplankton: application for inferring phytoplankton composition. Marine Ecology Progress Series 324:113-125.

Dodds LA, Black KD, Orr H, Roberts JM. 2009. Lipid biomarkers reveal geographical differences in food supply to the cold-water coral Lophelia pertusa (Scleractinia). Marine Ecology Progress Series 397:113-124.

Dorschel B, Hebbeln D, Foubert A, White M, Wheeler AJ. 2007. Hydrodynamics and coldwater coral facies distribution related to recent sedimentary processes at Galway Mound west of Ireland. Marine Geology 244:184-195.

Duineveld GCA, Jeffreys RM, Lavaleye MSS, Davies AJ, Bergman MJN, Watmough T, et al. 2012. Spatial and tidal variation in food supply to shallow cold-water coral reefs of the Mingulay Reef complex (Outer Hebrides, Scotland). Marine Ecology Progress Series 444:97-115.

Duineveld GCA, Lavaleye MSS, Berghuis EM. 2004. Particle flux and food supply to a seamount cold-water coral community (Galicia Bank, NW Spain). Marine Ecology Progress Series 277:13-23.

Duineveld GCA, Lavaleye MSS, Bergman MIN, De Stigter H, Mienis F. 2007. Trophic structure of a cold-water coral mound community (Rockall Bank, NE Atlantic) in relation to the near-bottom particle supply and current regime. Bulletin of Marine Science 81:449-467.

Edwards M, Johns DG, Leterme SC, Svendsen E, Richardson AJ. 2006. Regional climate change and harmful algal blooms in the northeast Atlantic. Limnology and Oceanography 51:820-829.

Emson RH, Young CM. 1994. Feeding mechanism of the brisingid starfish Novodinia antillensis. Marine Biology 118:433-442.

Fanelli E, Cartes JE, Papiol V. 2011. Food web structure of deep-sea macrozooplankton and micronekton off the Catalan slope: Insight from stable isotopes. Journal of Marine Systems 87:79-89.

Hebbeln D, Wienberg C, Wintersteller P, Freiwald A, Becker M, Beuck L, et al. 2014. Environmental forcing of the Campeche cold-water coral province, southern Gulf of Mexico. Biogeosciences 11:1799-1815.

Henry LA, Roberts JM. 2007. Biodiversity and ecological composition of macrobenthos on cold-water coral mounds and adjacent off-mound habitat in the bathyal Porcupine 

54:654-672.

Henson S, Lampitt R, Johns D. 2012. Variability in phytoplankton community structure in response to the North Atlantic Oscillation and implications for organic carbon flux. Limnology and Oceanography 57:1591-1601.

Hoffmann F, Radax R, Woebken D, Holtappels M, Lavik G, Rapp HT, et al. 2009. Complex nitrogen cycling in the sponge Geodia barretti. Environmental Microbiology 11:22282243.

Hovland M, Jensen S, Indreiten T. 2012. Unit pockmarks associated with Lophelia coral reefs off mid-Norway: more evidence of control by 'fertilizing' bottom currents. Geo-Marine Letters 32:545-554.

Howell KL, Pond DW, Billett DSM, Tyler PA. 2003. Feeding ecology of deep-sea seastars (Echinodermata: Asteroidea): a fatty-acid biomarker approach. Marine Ecology Progress Series 255:193-206.

Husebø Å, Nøttestad L, Fosså JH, Furevik DM, Jørgensen SB. 2002. Distribution and abundance of fish in deep-sea coral habitats. Hydrobiologia 471:91-99.

Iken K, Brey T, Wand U, Voigt J, Junghans P. 2001. Food web structure of the benthic community at the Porcupine Abyssal Plain (NE Atlantic): A stable isotope analysis. Progress in Oceanography 50:383-405.

Iverson SJ, Field C, Bowen WD, Blanchard W. 2004. Quantitative fatty acid signature analysis: A new method of estimating predator diets. Ecological Monographs 74:211235.

Jaworski A, Ragnarsson SA. 2006. Feeding habits of demersal fish in Icelandic waters: a multivariate approach. ICES Journal of Marine Science 63:1682-1694.

Kainz M, Arts MT, Mazumder A. 2004. Essential fatty acids in the planktonic food web and their ecological role for higher trophic levels. Limnology and Oceanography 49:17841793.

Kelly JR, Scheibling RE. 2012. Fatty acids as dietary tracers in benthic food webs. Marine Ecology Progress Series 446:1-22.

Kiriakoulakis K, Bett BJ, White M, Wolff GA. 2004. Organic biogeochemistry of the Darwin Mounds, a deep-water coral ecosystem, of the NE Atlantic. Deep-Sea Research Part IOceanographic Research Papers 51:1937-1954.

Kiriakoulakis K, Fisher E, Wolff GA, Freiwald A, Grehan A, Roberts JM, 2005. Lipids and nitrogen isotopes of two deep-water corals from the North-East Atlantic: inital results 
714

and implication for their nutrition. In: Freiwald A, Roberts JM, editors. Cold-Water Corals and Ecosystems. Berlin: Springer-Verlag, p 715-729.

Kutti T, Bannister RJ, Fosså JH. 2013. Community structure and ecological function of deepwater sponge grounds in the Traenadypet MPA-Northern Norwegian continental shelf. Continental Shelf Research 69:21-30.

Kutti T, Fosså JH, Bergstad OA. 2015. Influence of structurally complex benthic habitats on fish distribution. Marine Ecology Progress Series 520:175-190.

Lindberg B, Christensen O, Fosså JH, 2004. The geologic and morphologic setting of the Træna reef area based on high resolution acoustic data, Journal. University of Tromsø.

Mauchline J, Gordon JDM. 1980. The food and feeding of the deep-sea morid fish Lepidion eques (Gunther, 1887) in the Rockall Trough. Journal of the Marine Biological Association of the United Kingdom 60:1053-1059.

McClintock JB. 1994. Trophic biology of Antarctic shallow-water echinoderms. Marine Ecology Progress Series 111:191-202.

Meziane T, Tsuchiya M. 2000. Fatty acids as tracers of organic matter in the sediments and food web of a mangrove/intertidal flat ecosystem, Okinawa, Japan. Marine Ecology Progress Series 200:49-57.

Middelburg JJ, Barranguet C, Boschker HTS, Herman PMJ, Moens T, Heip CHR. 2000. The fate of intertidal microphytobenthos: $\mathrm{An}$ in situ ${ }^{13} \mathrm{C}$ labelling study. Limnology and Oceanography 45:1224-1234.

Mienis F, de Stigter HC, White M, Duineveld G, de Haas H, van Weering TCE. 2007. Hydrodynamic controls on cold-water coral growth and carbonate-mound development at the SW and SE Rockall Trough Margin, NE Atlantic Ocean. Deep-Sea Research Part I-Oceanographic Research Papers 54:1655-1674.

Mienis F, Duineveld GCA, Davies AJ, Ross SW, Seim H, Bane J, et al. 2012. The influence of near-bed hydrodynamic conditions on cold-water corals in the Viosca Knoll area, Gulf of Mexico. Deep-Sea Research Part I-Oceanographic Research Papers 60:32-45.

Mohn C, Rengstorf A, White M, Duineveld G, Mienis F, Soetaert K, et al. 2014. Linking benthic hydrodynamics and cold-water coral occurrences: A high-resolution model study at three cold-water coral provinces in the NE Atlantic. Progress in Oceanography 122:92-104.

Mueller CE, Larsson AI, Veuger B, Middelburg JJ, van Oevelen D. 2014. Opportunistic feeding on various organic food sources by the cold-water coral Lophelia pertusa. Biogeosciences 11:123-133. 
748 Mueller CE, Lundälv T, Middelburg JJ, van Oevelen D. 2013. The symbiosis between Lophelia pertusa and Eunice norvegica stimulates coral calcification and worm assimilation. Plos One 8:e58660.

Naumann MS, Orejas C, Wild C, Ferrier-Pages C. 2011. First evidence for zooplankton feeding sustaining key physiological processes in a scleractinian cold-water coral. Journal of Experimental Biology 214:3570-3576.

Phleger CF, Nelson MM, Groce AK, Cary SC, Coyne KJ, Nichols PD. 2005. Lipid

Painter SC, Lucas MI, Stinchcombe MC, Bibby TS, Poulton AJ. 2010. Summertime trends in pelagic biogeochemistry at the Porcupine Abyssal Plain study site in the northeast Atlantic. Deep-Sea Research Part II-Topical Studies in Oceanography 57:1313-1323.

Petursdottir H, Gislason A, Falk-Petersen S, Hop H, Svavarsson J. 2008. Trophic interactions of the pelagic ecosystem over the Reykjanes Ridge as evaluated by fatty acid and stable isotope analyses. Deep-Sea Research Part II-Topical Studies in Oceanography 55:8393.

$$
\text { composition of deep-sea hydrothermal vent tubeworm Riftia pachyptila, crabs }
$$
Munidopsis subsquamosa and Bythograea thermydron, mussels Bathymodiolus sp. and limpets Lepetodrilus spp. Comparative Biochemistry and Physiology Part B: Biochemistry and Molecular Biology 141:196-210.

R Development Core Team, 2015. R: A language and environment for statistical computing, Journal. R Foundation for Statistical Computing, Vienna, Austria.

Raine R, White M, Dodge JD. 2002. The summer distribution of net plankton dinoflagellates and their relation to water movements in the NE Atlantic Ocean, west of Ireland. Journal of Plankton Research 24:1131-1147.

Ravet JL, Brett MT, Arhonditsis GB. 2010. The effects of seston lipids on zooplankton fatty acid composition in Lake Washington, Washington, USA. Ecology 91:180-190.

Rix L, de Goeij JM, Mueller CE, Struck U, Middelburg JJ, van Duyl FC, et al. 2016. Coral mucus fuels the sponge loop in warm- and cold-water coral reef ecosystems. Scientific Reports 6:18715.

Roberts JM. 2005. Reef-aggregating behaviour by symbiotic eunicid polychaetes from coldwater corals: do worms assemble reefs? Journal of the Marine Biological Association of the United Kingdom 85:813-819.

Roberts JM, Wheeler AJ, Freiwald A. 2006. Reefs of the deep: The biology and geology of cold-water coral ecosystems. Science 312:543-547. 
781 Sherwood OA, Jamieson RE, Edinger EN, Wareham VE. 2008. Stable C and N isotopic composition of cold-water corals from the Newfoundland and Labrador continental slope: Examination of trophic, depth and spatial effects. Deep-Sea Research Part IOceanographic Research Papers 55:1392-1402.

Slagstad D, Tande KS, Wassman P. 1999. Modelled carbon fluxes as validated by field dta on the north Norwegian shelf during the productive period in 1994. Sarsia 84:303-317.

Soetaert K, Mohn C, Rengstorf A, Grehan A, van Oevelen D. 2016. Ecosystem engineering creates a direct nutritional link between 600-m deep cold-water coral mounds and surface productivity. Scientific Reports 6:35057.

Soffker M, Sloman KA, Hall-Spencer JM. 2011. In situ observations of fish associated with coral reefs off Ireland. Deep-Sea Research Part I-Oceanographic Research Papers 58:818-825.

Stevenson A, Rocha C. 2013. Evidence for the bioerosion of deep-water corals by echinoids in the Northeast Atlantic. Deep-Sea Research Part I-Oceanographic Research Papers 71:73-78.

Thiem O, Ravagnan E, Fosså JH, Berntsen J. 2006. Food supply mechanisms for cold-water corals along a continental shelf edge. Journal of Marine Systems 60:207-219.

van Duyl FC, Hegeman J, Hoogstraten A, Maier C. 2008. Dissolved carbon fixation by sponge-microbe consortia of deep water coral mounds in the northeastern Atlantic Ocean. Marine Ecology Progress Series 358:137-150.

Van Gaever S, Moodley L, de Beer D, Vanreusel A. 2006. Meiobenthos at the Arctic Håkon Mosby Mud Volcano, with a parental-caring nematode thriving in sulphide-rich sediments. Marine Ecology Progress Series 321:143-155.

Van Oevelen D, Duineveld GCA, Lavaleye MSS, Mienis F, Soetaert K, Heip CHR. 2009. The cold-water coral community as hotspot of carbon cycling on continental margins: a food web analysis from Rockall Bank (northeast Atlantic). Limnology and Oceanography 54:1829-1844.

Van Soest RWM, Lavaleye MSS. 2005. Diversity and abundance of sponges in bathyal coral reefs of Rockall Bank, NE Atlantic, from boxcore samples. Marine Biology Research $1: 338-349$.

Wagner H, Purser A, Thomsen L, Jesus CC, Lundälv T. 2011. Particulate organic matter fluxes and hydrodynamics at the Tisler cold-water coral reef. Journal of Marine Systems 85:19-29. 
814 Weisz JB, Lindquist N, Martens CS. 2008. Do associated microbial abundances impact 815 marine demosponge pumping rates and tissue densities? Oecologia 155:367-376.

816 White M, Wolff GA, Lundälv T, Guihen D, Kiriakoulakis K, Lavaleye M, et al. 2012. Cold-

817 water coral ecosystem (Tisler Reef, Norwegian Shelf) may be a hotspot for carbon 818 cycling. Marine Ecology Progress Series 465:11-23.

819 Wickham H, 2009. ggplot2: Elegant Graphics for Data Analysis. Springer-Verlag New York.

820 Wieczorek SK, Hooper RG. 1995. Relationship between diet and food availability in the

821 snow crab Chionoecetes opilio (O. Fabricius) in Bonne Bay, Newfoundland. Journal of $822 \quad$ Crustacean Biology 15:236-247.

823 Wild C, Mayr C, Wehrmann L, Schöttner S, Naumann M, Hoffmann F, et al. 2008. Organic

824 matter release by cold water corals and its implication for fauna-microbe interaction.

$825 \quad$ Marine Ecology Progress Series 372:67-75.

826 Yahel G, Whitney F, Reiswig HM, Eerkes-Medrano DI, Leys SP. 2007. In situ feeding and 827 metabolism of glass sponges (Hexactinellida, Porifera) studied in a deep temperate 828 fjord with a remotely operated submersible. Limnology and Oceanography 52:428-440. 
830 Table 1. List of examined species of the reef food web of the Træna deep coral reef field. The

831 species abbreviation (Abbr) is used in Table 3 and in Figures 2A and 3, $n$ indicates the

832 number of replicate specimens analysed for stable isotopes as presented in Fig. 2A.

\begin{tabular}{|c|c|c|c|c|}
\hline Abbr & Taxon & Species & Common name & $\mathbf{n}$ \\
\hline Bra_Bra & Brachiopoda & Brachiopoda sp. & lampshell & 1 \\
\hline Cep_Sep & Cephalopoda & Sepiola atlantica & Little cuttlefish & 2 \\
\hline Cni_Lop & Cnidaria & Lophelia pertusa & Deepwater white coral & 4 \\
\hline Cop_lar & Copepoda large & Calanus sp. (>280 um) & copepod & 2 \\
\hline Cop_sma & Copepoda small & Calanus sp. (>50 um) & copepod & 2 \\
\hline Cru_Lit & Decapoda & Lithodes maja & Norway king crab & 1 \\
\hline Cru_Mun & Decapoda & Munida rugosa & squat lobster & 3 \\
\hline Cru_Pan & Decapoda & Pandalus borealis & Northern shrimp & 7 \\
\hline Ech_Bon & Echiura & Bonellia sp. & Green spoonworm & 1 \\
\hline Ech_Hen & Asteroidea & Henricia pertusa & sea star & 4 \\
\hline Ech_Oph & Ophiuroidea & Ophiopholis aculeata & brittle star & 2 \\
\hline Ech_Par & Holothuroidea & Parastichopus tremulus & sea cucumber & 1 \\
\hline Eup_Meg & Euphausiacea & Meganyctiphanes norvegica & Northern krill & 6 \\
\hline Eup_Thy & Euphausiacea & Thysanoessa inermis & krill & 1 \\
\hline Pis_Arg & Pisces & Argentina sphyraena & Argentine & 1 \\
\hline Pis_Art & Pisces & Artediellus atlanticus & Atlantic hookear sculpin & 3 \\
\hline Pis_Bro & Pisces & Brosme brosme & Tusk & 12 \\
\hline Pis_Chi & Pisces & Chimaera monstrosa & Rabbit fish & 2 \\
\hline Pis_Hip & Pisces & Hippoglossoides platessoides & American plaice & 3 \\
\hline Pis_Mar & Pisces & Maurolicus muelleri & Silvery lightfish & 2 \\
\hline Pis_Phy & Pisces & Phycis blennoides & Greater forkbeard & 2 \\
\hline Pis_Pol & Pisces & Pollachius virens & Saith & 2 \\
\hline Pis_Seb & Pisces & Sebastes viviparus & Norway redfish & 1 \\
\hline Pis_Tri & Pisces & Trisopterus esmarkii & Norway pout & 6 \\
\hline Por_Dem & Porifera & Demospongia spp. & mix of large sponges & 18 \\
\hline Tun_Asc & Tunicata & Ascidia sp. & sea squirt & 1 \\
\hline SPM & Suspended matter & Suspended particulate matter & & 2 \\
\hline Sed_cwc & Sediment cwc & Sediment coral reef & & 6 \\
\hline Sed_off & Sediment off & Sediment off-reef & & 2 \\
\hline
\end{tabular}

833 
834 Table 2. List of examined species of the cold-water coral reef food web at Belgica Mounds.

835 The species abbreviation (Abbr) is used in Table 4 and in Figures $2 \mathrm{~B}$ and $4, n$ indicates the

836 number of replicate specimens analysed for the stable isotopes as presented in Fig. 2B.

\begin{tabular}{|c|c|c|c|c|}
\hline Abbr & Taxon & Species & Common name & $\mathbf{n}$ \\
\hline Biv_Hia & Bivalvia & Hiatella arctica & Wrinkled rockborer & 2 \\
\hline Cep_Bat & Cephalopoda & Bathypolypus bairdii & Spoonarm octopus & 2 \\
\hline Cni_Act & Cnidaria & Actinauge sp. & anemone & 1 \\
\hline Cni_Ant & Cnidaria & Anthomastus sp. & soft coral & 2 \\
\hline Cni_Cir & Cnidaria & Cirrhipathes sp. & Spiral wire coral & 2 \\
\hline Cni_Gor & Cnidaria & gorgonian spp. & gorgonian & 3 \\
\hline Cni_Hyd & Cnidaria & Hydrozoa spp. & hydroid polyp & 3 \\
\hline Cni_Lei & Cnidaria & Leiopathes sp. & Black coral & 3 \\
\hline Cni_Lop & Cnidaria & Lophelia pertusa & Deepwater white coral & 3 \\
\hline Cni_Mad & Cnidaria & Madrepora oculata & Zigzag coral & 3 \\
\hline Cru_Amp & Amphipoda & Amphipoda sp. & sandhopper & 1 \\
\hline Cru_Bat & Decapoda & Bathynectes sp. & crab & 3 \\
\hline Cru_Car & Decapoda & Caridea spp. & shrimp & 3 \\
\hline Cru_Cir & Cirripedia & Cirripedia spp. & barnacle & 3 \\
\hline Cru_Mun & Decapoda & Munida sp. & squat lobster & 5 \\
\hline Ech_Ast & Asteroidea & Asteroidea spp. & sea star & 3 \\
\hline Ech_Cid & Echinoidea & Cidaris sp. & sea urchin & 2 \\
\hline Ech_Ech & Echinoidea & Echinus sp. & sea urchin & - \\
\hline Ech_Oph & Ophiuroidea & Ophiuroidea spp. & brittle star & 2 \\
\hline Hol_Pso & Holothuroidea & Psolus sp. & sea cucumber & 1 \\
\hline Gas_Cal & Gastropoda & Calliostoma sp. & top snail & 3 \\
\hline Pis_Cat & Pisces & Cataetyx alleni & deep-sea bythitid fish & 2 \\
\hline Pis_Coe & Pisces & Coelorinchus abditilux & grenadier & 1 \\
\hline Pis_Cor & Pisces & Coryphaenoides rupestris & Roundnose grenadier & 1 \\
\hline Pis_Epi & Pisces & Epigonus telescopus & Black cardinal fish & 1 \\
\hline Pis_Gai & Pisces & Gaidropsarus vulgaris & Three-bearded rockling & 3 \\
\hline Pis_Gut & Pisces & Guttigadus latifrons & deep-sea morid fish & 1 \\
\hline Pis_Lep & Pisces & Lepidion eques & North Atlantic codling & 1 \\
\hline Pis_Neo & Pisces & Neocyttus helgae & oreo & 1 \\
\hline Pol_Eun & Polychaeta & Eunice norvegica & bristle worm & 3 \\
\hline Pol_Hes & Polychaeta & Hesionidae sp. & bristle worm & 3 \\
\hline Por_Aph & Porifera & Aphrocallistes sp. & glass sponge & 3 \\
\hline Por_Hex & Porifera & Hexactinellida sp. & glass sponge & 1 \\
\hline Por_Spo & Porifera & Spongosorites sp. & demosponge & 3 \\
\hline Tun_Sal & Tunicata & Salpidae sp. & salp & 1 \\
\hline SPM & Susp. part. mat. & & & 3 \\
\hline Trap & Sediment trap & & & 12 \\
\hline Zoo & Zooplankton & & & 2 \\
\hline
\end{tabular}


Table 3. Total fatty acid concentration (mean \pm standard deviation in $\mathrm{mg} \mathrm{C}^{-1} \mathrm{WW}$, except for Lophelia pertusa which is in mg C g $\mathrm{gW}^{-1}$

[skeleton + tissue]) based on ' $n$ ' specimens, and percentages (mean \pm standard deviation) of bacterial, algal and zooplankton fatty acids of species of the cold-water coral reef food web at the Træna deep coral reef field. The essential fatty acid markers are given in 'bold' or are listed under 'Essential fatty acids'. For taxa abbreviations see Table 1, ‘-‘ means not detected.

\begin{tabular}{|c|c|c|c|c|c|c|c|c|c|c|c|c|c|c|c|c|c|c|}
\hline \multirow[t]{2}{*}{ Taxa } & \multirow{2}{*}{$\frac{\text { Concentration }}{\mathrm{mg} \mathrm{C/g} \mathrm{WW}}$} & \multirow[b]{2}{*}{$\mathrm{n}$} & \multicolumn{6}{|c|}{ Bacterial markers (\%) } & \multicolumn{5}{|c|}{ Algal markers (\%) } & \multicolumn{3}{|c|}{ Zooplankton markers (\%) } & \multicolumn{2}{|c|}{ Essential fatty acids (\%) } \\
\hline & & & iC14:0 & iC15:0 & aic15:0 & iC17:0 & aic17:0 & $\mathrm{C} 18.1 \omega 7 \mathrm{c}$ & $\overline{C 16: 4 \omega 3}$ & C18:3w3 & $\mathrm{C} 18: 4 \omega 3$ & C20:5 23 & C22:6w3 & $\mathrm{C} 20: 1 \omega 9 \mathrm{c}$ & $C 22: 1 \omega 9$ & C22:1w11 & $\mathrm{C} 18: 2 \omega 6 \mathrm{c}$ & C20:4w6 \\
\hline Bra_Bra & $0.44 \pm 0.1$ & 3 & - & 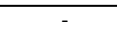 & - & $0.67 \pm 1.17$ & & $2.83 \pm 0.25$ & $0.42 \pm 0.73$ & 3 & & $3.93 \pm 1.14$ & $10.74 \pm 2.67$ & $1.7 \pm 2.95$ & - & 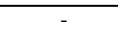 & $0.43 \pm 0.75$ & $4.25 \pm 2.03$ \\
\hline Cep_Sep & $9.38 \pm 6.79$ & 2 & - & - & - & $0.31 \pm 0.08$ & & $1.8 \pm 0.24$ & $0.19 \pm 0.26$ & - & $0.09 \pm 0.13$ & $15.79 \pm 1.82$ & $34.77 \pm 1.03$ & $1.64 \pm 0.46$ & & $0.09 \pm 0.13$ & $0.4 \pm 0.16$ & $1.78 \pm 0.69$ \\
\hline Cni_Lop & $1.03 \pm 0.34$ & 4 & $0.05 \pm 0.02$ & $0.1 \pm 0.05$ & $0.03 \pm 0.01$ & $0.61 \pm 0.39$ & $0.19 \pm 0.02$ & $0.18 \pm 0.01$ & $0.21 \pm 0.02$ & & $0.23 \pm 0.18$ & $0.34 \pm 0.04$ & $1.01 \pm 0.13$ & $5.76 \pm 6.73$ & $1.85 \pm 0.15$ & $\begin{array}{ll}5 & 0.2 \pm 0.07\end{array}$ & $1.11 \pm 0.07$ & $12.08 \pm 3.34$ \\
\hline Cop_lar & $28.57 \pm 3.04$ & 2 & - & $0.3 \pm 0$ & $0.26 \pm 0$ & - & - & $0.52 \pm 0$ & $0.37 \pm 0.01$ & $2.78 \pm 0$ & $10.73 \pm 0.04$ & $42.54 \pm 0.65$ & $12.8 \pm 2.05$ & $0.4 \pm 0.01$ & $0.28 \pm 0.39$ & - & $1.16 \pm 0$ & $0.29 \pm 0.05$ \\
\hline Cop_sma & $49.64 \pm 7.88$ & 2 & $0.02 \pm 0.02$ & $0.15 \pm 0.16$ & $0.23 \pm 0$ & - & $0.09 \pm 0.03$ & $0.5 \pm 0.07$ & $0.3 \pm 0.06$ & $2.54 \pm 0.15$ & $9.48 \pm 0.84$ & $1.29 \pm 1.13$ & $13.28 \pm 0.93$ & $0.33 \pm 0.08$ & $1.27 \pm 1.8$ & - & $0.92 \pm 0.19$ & $0.21 \pm 0.06$ \\
\hline Cru_Lit & 0.54 & 1 & - & - & - & - & - & 7.71 & - & - & 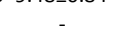 & 7.06 & 5.44 & 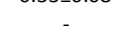 & 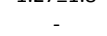 & - & - & 6.27 \\
\hline Cru_Mun & $3.23 \pm 1.06$ & 2 & - & - & - & $0.37 \pm 0.01$ & $0.09 \pm 0$ & $4.71 \pm 0.09$ & $0.94 \pm 0.07$ & - & $0.2 \pm 0.03$ & $17.72 \pm 0.42$ & $17.71 \pm 0.13$ & $1.05 \pm 0.1$ & - & - & $1.19 \pm 0.1$ & $2.15 \pm 0.03$ \\
\hline Cru_Pan & $2.9 \pm 0.68$ & 6 & - & $0.1 \pm 0.05$ & - & $0.47 \pm 0.18$ & $0.13 \pm 0.11$ & $5.93 \pm 0.44$ & $0.21 \pm 0.13$ & . & $0.12 \pm 0.07$ & $13.28 \pm 1.17$ & $16.67 \pm 2.71$ & $0.58 \pm 0.15$ & . & $0.08 \pm 0.13$ & $0.91 \pm 0.15$ & $1.42 \pm 1.62$ \\
\hline Ech_Hen & $0.89 \pm 0.48$ & 3 & $0.34 \pm 0.33$ & $2.1 \pm 0.89$ & $0.83 \pm 0.26$ & $1.85 \pm 0.69$ & $0.57 \pm 0.22$ & $11.29 \pm 3.14$ & $0.39 \pm 0.43$ & . & - & $1 \pm 0.36$ & $0.52 \pm 0.07$ & - & - & - & $0.75 \pm 0.56$ & $7.62 \pm 6.63$ \\
\hline Ech_Oph & $8.58 \pm 10.27$ & 4 & $0.17 \pm 0.12$ & $1.17 \pm 0.29$ & $0.65 \pm 0.25$ & $0.72 \pm 0.15$ & $0.18 \pm 0.14$ & $3.23 \pm 1.23$ & $0.18 \pm 0.24$ & & $2.71 \pm 1.3$ & $6.05 \pm 4.15$ & $2.42 \pm 1.74$ & $5.35 \pm 2.14$ & - & $0.23 \pm 0.26$ & $1.25 \pm 0.31$ & $2.08 \pm 0.99$ \\
\hline Ech_Par & 0.2 & 1 & - & 3.75 & 2 & 4.08 & - & 3.76 & & - & 1.29 & 3.42 & 3.91 & - & - & - & - & 11.04 \\
\hline Eup_Meg & $3.43 \pm 0.85$ & 3 & - & $0.08 \pm 0.13$ & - & $0.31 \pm 0.12$ & - & $3.42 \pm 0.32$ & $0.3 \pm 0.07$ & & $0.46 \pm 0.54$ & $7.41 \pm 2.14$ & $25.57 \pm 3.57$ & $1.04 \pm 0.27$ & - & $0.14 \pm 0.24$ & $1.51 \pm 0.29$ & $0.87 \pm 0.18$ \\
\hline Eup_Thy & $48.54 \pm 65.07$ & 2 & - & $0.08 \pm 0.11$ & - & $0.52 \pm 0.74$ & - & $5.65 \pm 2.32$ & $0.32 \pm 0.45$ & $\xi$ & $2.41 \pm 0.85$ & $16.91 \pm 2.33$ & $18.68 \pm 17.55$ & $0.09 \pm 0.13$ & - & $0.22 \pm 0.31$ & $1.98 \pm 1.32$ & $0.17 \pm 0.24$ \\
\hline Pis_Arg & $1.99 \pm 0.55$ & 2 & - & $0.08 \pm 0.11$ & - & $0.26 \pm 0.03$ & 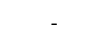 & $2.75 \pm 0.29$ & $0.34 \pm 0.04$ & - & $0.32 \pm 0.15$ & $4.65 \pm 0.49$ & $29.95 \pm 11.26$ & $0.64 \pm 0.14$ & - & $0.5 \pm 0.07$ & $1.01 \pm 0.18$ & $1.17 \pm 0.09$ \\
\hline Pis_Art & $1.62 \pm 0.84$ & 3 & - & . & - & $0.71 \pm 0.26$ & $0.09 \pm 0.15$ & $3.89 \pm 2$ & $0.12 \pm 0.1$ & - & & $8.01 \pm 3.16$ & $25.8 \pm 15.3$ & $0.53 \pm 0.21$ & - & $0.08 \pm 0.13$ & $0.83 \pm 0.17$ & $5.96 \pm 0.83$ \\
\hline Pis_Bro & $3.88 \pm 2.46$ & 6 & $0.04 \pm 0.15$ & $0.18 \pm 0.03$ & $0.02 \pm 0.02$ & $0.29 \pm 0.05$ & $0.13 \pm 0.08$ & $0.41 \pm 0.86$ & $0.08 \pm 0.03$ & - & $0.06 \pm 0.06$ & $0.03 \pm 0.05$ & $12.98 \pm 4.36$ & $10.14 \pm 3.49$ & $93.09 \pm 4.06$ & $65.64 \pm 4.29$ & $1 \pm 0.14$ & $3.34 \pm 0.72$ \\
\hline Pis_Chi & $2.9 \pm 0.49$ & 2 & 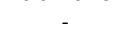 & & - & $0.68 \pm 0.16$ & $0.17 \pm 0.06$ & $3.98 \pm 0.09$ & $0.58 \pm 0.13$ & - & - & $6.29 \pm 0.56$ & $34.94 \pm 1.92$ & $0.47 \pm 0.04$ & & $0.22 \pm 0.01$ & $0.44 \pm 0.02$ & $4.3 \pm 0.33$ \\
\hline Pis_Hip & $1.45 \pm 0.31$ & 3 & - & - & - & $0.58 \pm 0.26$ & - & $2.86 \pm 1.84$ & - & - & 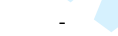 & $12.41 \pm 2.37$ & $29.66 \pm 9.95$ & $0.68 \pm 0.22$ & - & $0.2 \pm 0.17$ & $1.33 \pm 0.56$ & $7.81 \pm 0.72$ \\
\hline Pis_Mar & $75.49 \pm 0.64$ & 3 & - & $0.4 \pm 0.09$ & $0.14 \pm 0.02$ & $0.48 \pm 0.08$ & $0.08 \pm 0.01$ & $1.81 \pm 0.57$ & $0.23 \pm 0.05$ & ; & $0.74 \pm 0.2$ & $29.42 \pm 1.07$ & $4.49 \pm 0.52$ & 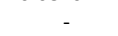 & - & $0.28 \pm 0.14$ & $0.97 \pm 0.05$ & $0.2 \pm 0.05$ \\
\hline Pis_Phy & $1.8 \pm 0.35$ & 2 & - & - & - & $0.33 \pm 0.13$ & - & $2.93 \pm 0.27$ & $0.06 \pm 0.09$ & - & $0.13 \pm 0.04$ & $4.77 \pm 6.75$ & $31.4 \pm 3.69$ & $1.59 \pm 0.86$ & - & $0.56 \pm 0.35$ & $0.77 \pm 0.04$ & $6.54 \pm 3.35$ \\
\hline Pis_Pol & $16.28 \pm 1.04$ & 2 & - & . & - & - & - & $4.31 \pm 1.16$ & . & $0.68 \pm 0$. & $0.67 \pm 0.19$ & $1.07 \pm 0.46$ & $1.24 \pm 1.75$ & $0.73 \pm 0.46$ & - & . & $1.34 \pm 0.8$ & $2.59 \pm 0.18$ \\
\hline Pis_Seb & $8.15 \pm 8.89$ & 3 & - & $0.04 \pm 0.06$ & $0.01 \pm 0.02$ & $0.25 \pm 0.02$ & - & $1.8 \pm 0.29$ & $0.04 \pm 0.06$ & 5 & $0.37 \pm 0.07$ & $7.94 \pm 1.08$ & $24.2 \pm 21.02$ & $0.4 \pm 0.35$ & $0.75 \pm 1.3$ & $0.28 \pm 0.25$ & $3.38 \pm 0.33$ & $1.83 \pm 0.62$ \\
\hline Pis_Tri & $4.28 \pm 0.66$ & 2 & - & $0.08 \pm 0.11$ & - & $0.21 \pm 0.01$ & 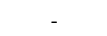 & $2.24 \pm 0.91$ & $0.23 \pm 0.03$ & 3 & $0.29 \pm 0.13$ & $8.19 \pm 0.73$ & $35.99 \pm 1.81$ & $0.74 \pm 0.19$ & - & $1.99 \pm 2.34$ & $0.73 \pm 0.09$ & $1.14 \pm 0.48$ \\
\hline Por_Dem & $0.67 \pm 0.48$ & 17 & $0.14 \pm 0.27$ & $1.85 \pm 1.77$ & $1.49 \pm 1.42$ & $1.24 \pm 1.31$ & $1.26 \pm 1.98$ & $4.41 \pm 2.38$ & $0.73 \pm 1.1$ & $0.24 \pm 0.53$ & $3 \quad 1.07 \pm 1.6$ & $2.1 \pm 2.31$ & $5.27 \pm 7.22$ & $1.06 \pm 0.91$ & - & $0.5 \pm 0.98$ & $0.38 \pm 0.4$ & $0.75 \pm 0.8$ \\
\hline Sed_cwc & $0.01 \pm 0.004$ & 6 & $0.68 \pm 0.38$ & $2.63 \pm 0.66$ & $3.07 \pm 0.56$ & $2.35 \pm 0.79$ & $0.71 \pm 0.38$ & $5.93 \pm 2.59$ & - & - & $0.59 \pm 0.52$ & $0.4 \pm 0.63$ & $1.88 \pm 1.48$ & $2.66 \pm 3.26$ & $2.1 \pm 1.49$ & - & $0.59 \pm 0.33$ & $3.24 \pm 2.15$ \\
\hline Sed_off & $0.009 \pm 1 \cdot 10^{-6}$ & 2 & $0.94 \pm 0.01$ & $2.99 \pm 0.16$ & $3.41 \pm 0.07$ & $3.03 \pm 0.11$ & $0.94 \pm 0.07$ & $8.07 \pm 0.85$ & - & - & $0.65 \pm 0.92$ & - & $1.68 \pm 0.13$ & $1.89 \pm 2.68$ & $2.13 \pm 0.07$ & - & $0.32 \pm 0.45$ & $5 \pm 0.54$ \\
\hline Tun_Asc & $0.41 \pm 0.58$ & 3 & - & 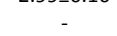 & - & - & - & $9.59 \pm 5.73$ & - & - & $1.61 \pm 2.78$ & $4.08 \pm 4.41$ & $12.5 \pm 6.13$ & & 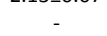 & - & - & $14.31 \pm 9.37$ \\
\hline
\end{tabular}




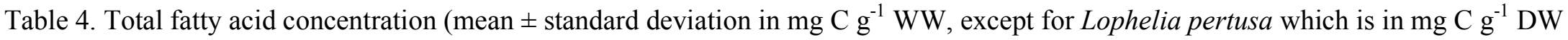

[skeleton + tissue]) based on ' $n$ ' samples, and percentages (mean \pm standard deviation) of bacterial, algal and zooplankton fatty acids of taxa of the reef food web at Belgica Mounds. Essential fatty acids are in 'bold' or are listed under 'Essential fatty acids'. For taxa abbreviations see

Table 2, ‘-‘ means not detected.

\begin{tabular}{|c|c|c|c|c|c|c|c|c|c|c|c|c|c|c|c|c|c|c|}
\hline \multirow[t]{2}{*}{ Taxa } & \multirow{2}{*}{$\begin{array}{r}\text { Concentration } \\
\mathrm{mg} \mathrm{C} / \mathrm{g} \mathrm{WW}\end{array}$} & \multicolumn{7}{|c|}{ Bacterial markers (\%) } & \multicolumn{5}{|c|}{ Algal markers (\%) } & \multicolumn{3}{|c|}{ Zooplankton markers (\%) } & \multicolumn{2}{|c|}{ Essential fatty acids (\%) } \\
\hline & & $\mathrm{n}$ & iC14:0 & iC15:0 & aiC15:0 & ic17:0 & aiC17:0 & $\overline{c 18.1 \omega 7 c}$ & $C 16: 4 \omega 3$ & $C 18: 3 \omega 3$ & $\mathrm{C} 18: 4 \omega 3$ & C20:5 53 & C22:6w3 & $c 20: 1 \omega 9 c$ & $\mathrm{C} 22: 1 \omega 9$ & $C 22: 1 \omega 11$ & $C 18: 2 \omega 6 c$ & $C 20: 4 \omega 6$ \\
\hline Biv_Hia & $1.34 \pm 0.51$ & 2 & - & - & & $0.49 \pm 0.09$ & & $0.94 \pm 0.42$ & - & $0.12 \pm 0.16$ & $0.39 \pm 0.17$ & $8.81 \pm 12.47$ & $15.11 \pm 0.15$ & $0.35 \pm 0.01$ & & - & $2.01 \pm 0.15$ & $9.85 \pm 2.98$ \\
\hline Cep_Bat & $0.87 \pm 0.13$ & 2 & - & - & - & - & 8 & $1.33 \pm 0.13$ & - & - & - & $19.62 \pm 5.32$ & $30.64 \pm 4.88$ & 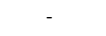 & - & - & 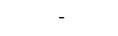 & $7.89 \pm 1.04$ \\
\hline Cni_Act & 1 & 1 & - & - & - & 0.89 & - & 2.49 & - & - & - & 13.95 & 10.96 & 2.54 & - & - & 0.44 & 1.53 \\
\hline Cni_Ant & $0.74 \pm 0.62$ & 4 & - & - & - & $0.14 \pm 0.28$ & & $3.15 \pm 0.99$ & - & - & $0.24 \pm 0.47$ & $5.56 \pm 4.88$ & $3.94 \pm 1.85$ & $3.46 \pm 0.46$ & - & - & $0.36 \pm 0.45$ & $22.3 \pm 10.67$ \\
\hline Cni_Gor & $1.86 \pm 1.23$ & 3 & - & $0.29 \pm 0.25$ & $0.58 \pm 0.59$ & $2.3 \pm 2.04$ & $0.03 \pm 0.06$ & $2.24 \pm 0.28$ & - & - & - & $5.44 \pm 1.23$ & $3.25 \pm 0.67$ & $0.82 \pm 0.22$ & - & - & $0.81 \pm 0.28$ & $12.29 \pm 2.36$ \\
\hline Cni_Hyd & $11.09 \pm 3.21$ & 3 & $0.26 \pm 0.09$ & $0.62 \pm 0.2$ & $0.29 \pm 0.09$ & $0.74 \pm 0.16$ & $0.28 \pm 0.08$ & $2.52 \pm 0.11$ & 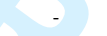 & - & - & $3.4 \pm 1.61$ & $4.08 \pm 2.98$ & $0.43 \pm 0.05$ & - & - & $0.95 \pm 0.32$ & $3.37 \pm 2.54$ \\
\hline Cni_Lei & $8.46 \pm 2.01$ & 3 & - & $0.05 \pm 0.08$ & & $0.44 \pm 0.03$ & & $3.68 \pm 0.23$ & & 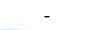 & 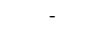 & $14.3 \pm 0.78$ & $0.63 \pm 0.22$ & $1.19 \pm 0.11$ & - & - & $0.92 \pm 0.18$ & $2.33 \pm 0.79$ \\
\hline Cni_Lop & $0.81 \pm 0.76$ & , & - & $0.11 \pm 0.2$ & - & $1.17 \pm 0.76$ & & $2.58 \pm 0.04$ & $2.61 \pm 4.53$ & & $0.29 \pm 0.51$ & $7.27 \pm 6.29$ & $4.71 \pm 3.29$ & $2.04 \pm 1.97$ & & $2.24 \pm 3.87$ & $0.82 \pm 0.72$ & $2.52 \pm 1.55$ \\
\hline Cni_Mad & $1.81 \pm 1.13$ & 3 & - & $0.04 \pm 0.06$ & - & $1.33 \pm 0.87$ & $0.03 \pm 0.06$ & $1.59 \pm 1.25$ & $0.1 \pm 0.18$ & - & $0.19 \pm 0.32$ & $8.58 \pm 7.37$ & $5.79 \pm 1.1$ & $1.84 \pm 2.15 \mathrm{C}$ & $0.57 \pm 0.99$ & $1.87 \pm 3.23$ & $0.97 \pm 0.39$ & $5.34 \pm 3.65$ \\
\hline Cru_Amp & 92.36 & 1 & - & - & 0.06 & - & - & 24.44 & 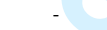 & - & 1.49 & 6.61 & 9.55 & 0.43 & - & - & 1.22 & 1.26 \\
\hline Cru_Car & $2.34 \pm 0.34$ & 2 & - & - & 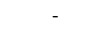 & $0.29 \pm 0.01$ & & $5.61 \pm 0.65$ & - & & $0.18 \pm 0.26$ & $16.31 \pm 2.15$ & $15.94 \pm 1.83$ & $0.14 \pm 0.02$ & - & - & $0.88 \pm 0$ & $2.97 \pm 0.45$ \\
\hline Cru_cir & $27.67 \pm 25.36$ & 3 & - & $0.25 \pm 0.05$ & - & - & - & $1.81 \pm 0.18$ & - & $0.26 \pm 0.45$ & $0.6 \pm 1.04$ & $4.64 \pm 8.04$ & $10.21 \pm 1.4$ & $0.34 \pm 0.02$ & - & - & $1.08 \pm 0.17$ & $0.61 \pm 0.27$ \\
\hline Cru_Mun & $3.5 \pm 0.77$ & 5 & $0.09 \pm 0.21$ & $0.52 \pm 1.14$ & - & $0.25 \pm 0.05$ & $0.08 \pm 0.02$ & $0.81 \pm 1.53$ & $0.03 \pm 0.02$ & - & $0.14 \pm 0.02$ & & $14.93 \pm 1.96$ & $1.11 \pm 0.41 \mathrm{C}$ & $0.05 \pm 0.08$ & 8 $0.38 \pm 0.43$ & $0.64 \pm 0.37$ & $13.72 \pm 1.7$ \\
\hline Ech_Ast & $0.37 \pm 0.09$ & 3 & $0.8 \pm 1.24$ & $0.22 \pm 0.08$ & $0.14 \pm 0.13$ & $0.09 \pm 0.09$ & $0.05 \pm 0.05$ & $1.8 \pm 0.65$ & $0.02 \pm 0.04$ & - & & $0.03 \pm 0.04$ & $0.92 \pm 0.38$ & $1.84 \pm 3.18$ & - & - & $0.08 \pm 0.13$ & $17.48 \pm 3.85$ \\
\hline Ech_cid & $0.34 \pm 0.04$ & 3 & - & $0.07 \pm 0.06$ & - & $0.3 \pm 0.27$ & - & $3.82 \pm 0.91$ & - & - & 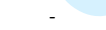 & $2.22 \pm 2.23$ & $0.5 \pm 0.86$ & $0.45 \pm 0.77$ & - & - & $0.11 \pm 0.1$ & $16.67 \pm 14.35$ \\
\hline Ech_Ech & 0.56 & 1 & - & - & - & 0.63 & - & 1.58 & - & - & - & 9.29 & 4.26 & 7.69 & - & - & 0.29 & 22.8 \\
\hline Ech_Oph & $6.82 \pm 0.45$ & 2 & $0.21 \pm 0.11$ & $0.52 \pm 0.16$ & $0.42 \pm 0.18$ & $0.27 \pm 0.38$ & $0.1 \pm 0.02$ & $3.21 \pm 0.37$ & - & - & $1.8 \pm 0.44$ & $12.83 \pm 1.26$ & $3.05 \pm 0.36$ & $0.75 \pm 0$ & - & - & $0.78 \pm 0.14$ & $2.78 \pm 1.58$ \\
\hline Gas_Cal & $2.8 \pm 0.13$ & 3 & - & 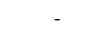 & $0.03 \pm 0.05$ & $0.34 \pm 0.13$ & $0.28 \pm 0.06$ & $3.73 \pm 0.22$ & - & - & 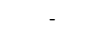 & $5.23 \pm 4.56$ & $1.59 \pm 0.17$ & $0.07 \pm 0.13$ & - & - & $1.26 \pm 0.34$ & $16.03 \pm 1.41$ \\
\hline Hol_Pso & 0.91 & 1 & - & 0.35 & - & - & 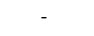 & 1.29 & - & - & - & 13.55 & 5.74 & 0.81 & - & - & 0.27 & 23.53 \\
\hline Pis_Cat & $1.83 \pm 0$ & 2 & - & - & - & $0.51 \pm 0.07$ & - & $3 \pm 0.26$ & - & - & - & $5.71 \pm 0.52$ & $32.41 \pm 7.07$ & $0.22 \pm 0.31$ & - & - & $1.04 \pm 0.04$ & $3.06 \pm 0.59$ \\
\hline Pis_Coe & 1.22 & 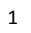 & - & - & - & - & - & 1.21 & 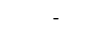 & 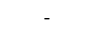 & - & 8.49 & 42.88 & & - & - & 0.42 & 6.65 \\
\hline Pis_Epi & 32.36 & 1 & - & - & - & 0.22 & - & 3.03 & - & - & - & 23.22 & 8.59 & 2.04 & - & - & 0.77 & 0.82 \\
\hline Pis_lep & $0.78 \pm 0.19$ & 4 & - & - & - & $0.08 \pm 0.17$ & - & $1.88 \pm 0.31$ & - & - & $0.07 \pm 0.13$ & $3.94 \pm 2.96$ & $29.45 \pm 2.73$ & $0.08 \pm 0.17$ & - & - & $0.6 \pm 0.18$ & $3.03 \pm 1.38$ \\
\hline Pis_Neo & 1.81 & 1 & - & - & - & 0.3 & - & 2.23 & 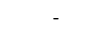 & 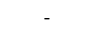 & - & 7.17 & 10.58 & 1.02 & - & - & 0.82 & 1.81 \\
\hline Pol_Eun & $2.81 \pm 0.66$ & 2 & - & $0.07 \pm 0.1$ & $0.05 \pm 0.07$ & $0.24 \pm 0.07$ & - & $1.92 \pm 0.31$ & - & - & $0.52 \pm 0.15$ & $17.48 \pm 1.82$ & $6.86 \pm 0.61$ & $0.51 \pm 0.02$ & - & - & $1.05 \pm 0.01$ & $4.24 \pm 0.72$ \\
\hline Pol_Hes & $10.85 \pm 9.64$ & 3 & - & $0.06 \pm 0.05$ & - & - & - & $3.7 \pm 0.34$ & 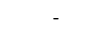 & - & $0.37 \pm 0.48$ & $6.65 \pm 6.1$ & $17.54 \pm 4.55$ & $0.32 \pm 0.04$ & - & - & $1.52 \pm 0.34$ & $0.73 \pm 0.33$ \\
\hline Por_Aph & $0.17 \pm 0.04$ & 3 & - & - & - & - & - & $1.25 \pm 2.16$ & - & - & - & $5.93 \pm 4.08$ & $33.35 \pm 26.02$ & - & - & - & - & $4.67 \pm 4.3$ \\
\hline Por_Hex & 0.15 & 1 & - & - & - & - & & 8.62 & - & - & - & 8.41 & 3.47 & - & - & - & 2.04 & 5.9 \\
\hline Por_Spo & $1.01 \pm 0.75$ & 3 & - & - & $2.4 \pm 0.68$ & $3.53 \pm 2$ & $0.76 \pm 0.43$ & $5.44 \pm 0.75$ & - & 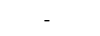 & - & $0.14 \pm 0.25$ & $4.84 \pm 6.33$ & 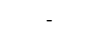 & - & - & $0.08 \pm 0.15$ & \\
\hline SPM & $0.01 \pm 0.01$ & 3 & - & $0.15 \pm 0.26$ & $0.45 \pm 0.48$ & - & & $3.47 \pm 0.54$ & $1.54 \pm 1.39$ & - & - & & $2.77 \pm 3.91$ & $0.14 \pm 0.25$ & - & - & $4.13 \pm 0.95$ & $1.37 \pm 1.46$ \\
\hline Tun_Sal & $0.41 \pm 0.26$ & 3 & - & $0.67 \pm 0.67$ & $0.64 \pm 0.67$ & $0.49 \pm 0.43$ & & $0.96 \pm 0.88$ & & - & $1.65 \pm 2.86$ & $2.93 \pm 5.07$ & $10.15 \pm 10.58$ & $0.08 \pm 0.14$ & - & - & $0.99 \pm 0.93$ & $1.16 \pm 1.1$ \\
\hline
\end{tabular}


Figure 1. Sample locations at (A) the Træna Deep Coral Reef field indicated as black dots and the white box shows the border of the Træna MPA on the Norwegian shelf (inset) and (B) the Belgica Mounds province on the Irish margin (inset map) with the investigated coral mound enclosed in a white square.

Figure 2. Mean ( \pm standard deviation) $\delta^{13} \mathrm{C}(\%)$ and $\delta^{15} \mathrm{~N}(\%)$ values for various organic matter sources, reef fauna and fishes at Træna (A) and Belgica Mounds (B). Samples are sorted alphabetically with fish species highlighted in red. Abbreviations for panel A can be found in Table 1 and for panel B in Table 2.

Figure 3. Proportion of (A) summed bacterial fatty acids, (B) summed algal fatty acids, (C) summed zooplankton fatty acids and (D) summed essential fatty acids of species of the Træna deep coral reef field. Errors bars indicate standard deviation calculated from the replicate samples indicated in Table 3. See Table 1 for abbreviations.

Figure 4. Proportion of (A) summed bacterial fatty acids, (B) summed algal fatty acids, (C) summed zooplankton fatty acids and (D) summed essential fatty acids of species of the Belgica Mounds. Errors bars indicate standard deviation calculated from the replicate samples indicated in Table 4. See Table 2 for abbreviations.

Figure 5. Time series from October 2011 to October 2012 of A) fluorescence signal (in relative units), B) chlorophyll $a$ deposition $\left(\mathrm{ng} \mathrm{m}^{-2} \mathrm{~d}^{-1}\right)$ in the sediment trap and C) number of visible aggregates on a still image. The inset figure on the left shows image from period with no visible aggregates (2-Nov-2011) and inset figure on the right shows an example image from period (2-May-2012) with 
visible aggregates in the picture (i.e. the whitish specks in the dark top part of the inset figure).

Figure 6. PC1 and PC2 plot of the principle component analysis of the summed specific fatty acids for algae, bacteria and zooplankton with sites Træna and Belgica mounds as group factor. Normal distribution ellipsoids are indicated.

Figure 7. PC1 and PC2 plots of the principal component analysis of the summed specific fatty acids for algae, bacteria and zooplankton for A) Cnidarian samples with sites Træna and Belgica Mounds as group factor, B) Cnidarian samples with sites and taxa as group factor, C) Pisces samples with sites Træna and Belgica Mounds as group factor, D) Pisces samples with sites and taxa as group factor. Normal distribution ellipsoids are indicated. Abbreviations in the legends of subplot B and D are denoted as "TR_" for Træna and "BM_" for Belgica Mounds followed by the taxa abbreviation, which can be found in Table 1 and 2 for Træna and Belgica Mounds, respectively.

Figure 8. $\delta^{13} \mathrm{C}(\%)$ and $\delta^{15} \mathrm{~N}(\%)$ values of individual sponge samples at the Træna coral reef (open symbols) and Belgica Mounds (closed symbols). 

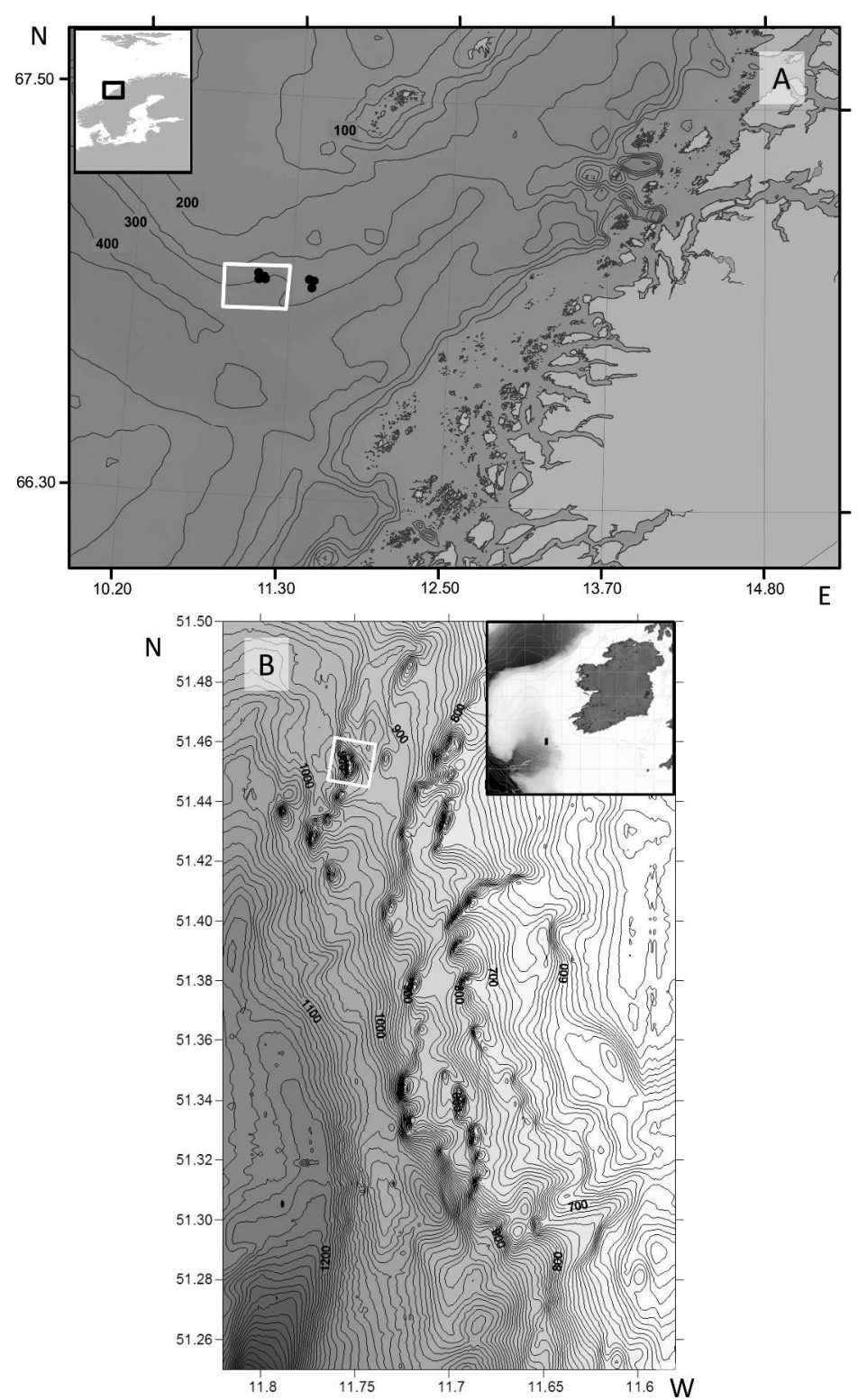

Sample locations at $(A)$ the Træna Deep Coral Reef field indicated as black dots and the white box shows the border of the Træna MPA on the Norwegian shelf (inset) and (B) the Belgica Mounds province on the Irish margin (inset map) with the investigated coral mound enclosed in a white square.

$$
275 \times 397 \mathrm{~mm}(300 \times 300 \text { DPI) }
$$



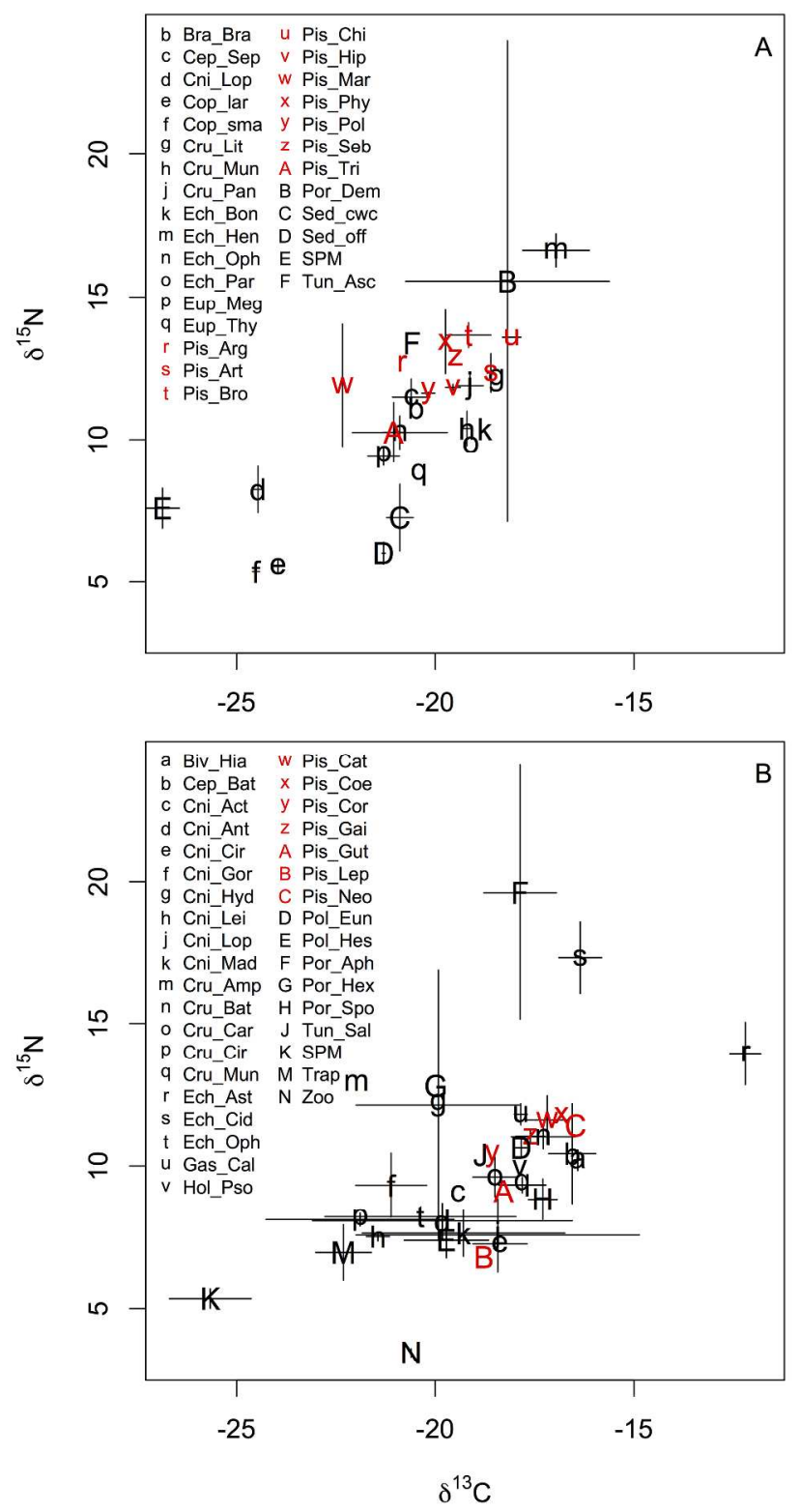

Mean ( standard deviation) $\delta^{13} \mathrm{C}\left(\%\right.$ ) and $\delta^{15} \mathrm{~N}(\%$ ) values for various organic matter sources, reef fauna and fishes at Træna (A) and Belgica Mounds (B). Samples are sorted alphabetically with fish species highlighted in red. Abbreviations for panel A can be found in Table 1 and for panel B in Table 2.

$275 \times 397 \mathrm{~mm}(300 \times 300 \mathrm{DPI})$ 

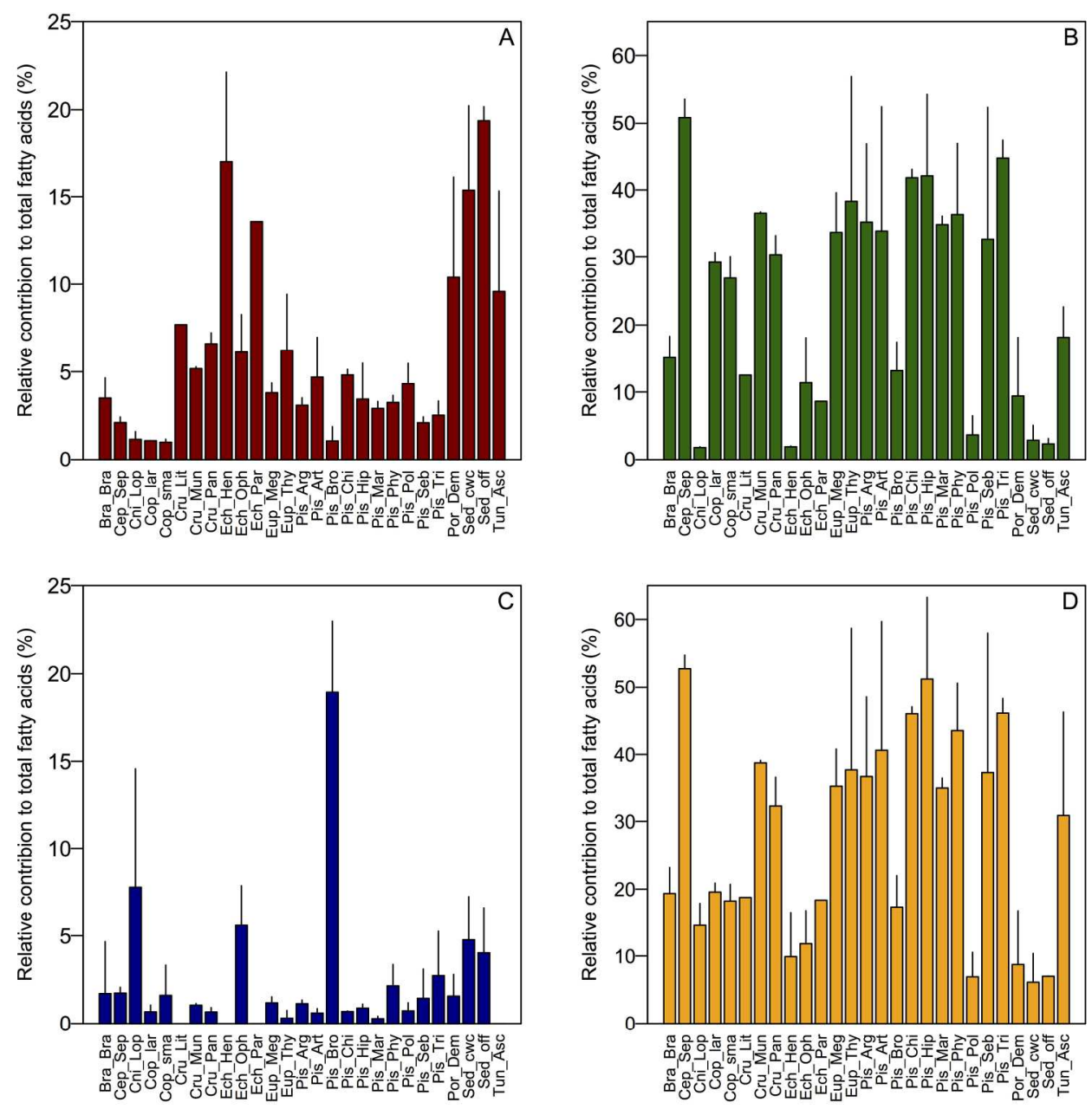

Proportion of (A) summed bacterial fatty acids, (B) summed algal fatty acids, (C) summed zooplankton fatty acids and (D) summed essential fatty acids of species of the Træna deep coral reef field. Errors bars indicate standard deviation calculated from the replicate samples indicated in Table 3. See Table 1 for abbreviations.

$$
203 \times 203 \mathrm{~mm}(300 \times 300 \mathrm{DPI})
$$



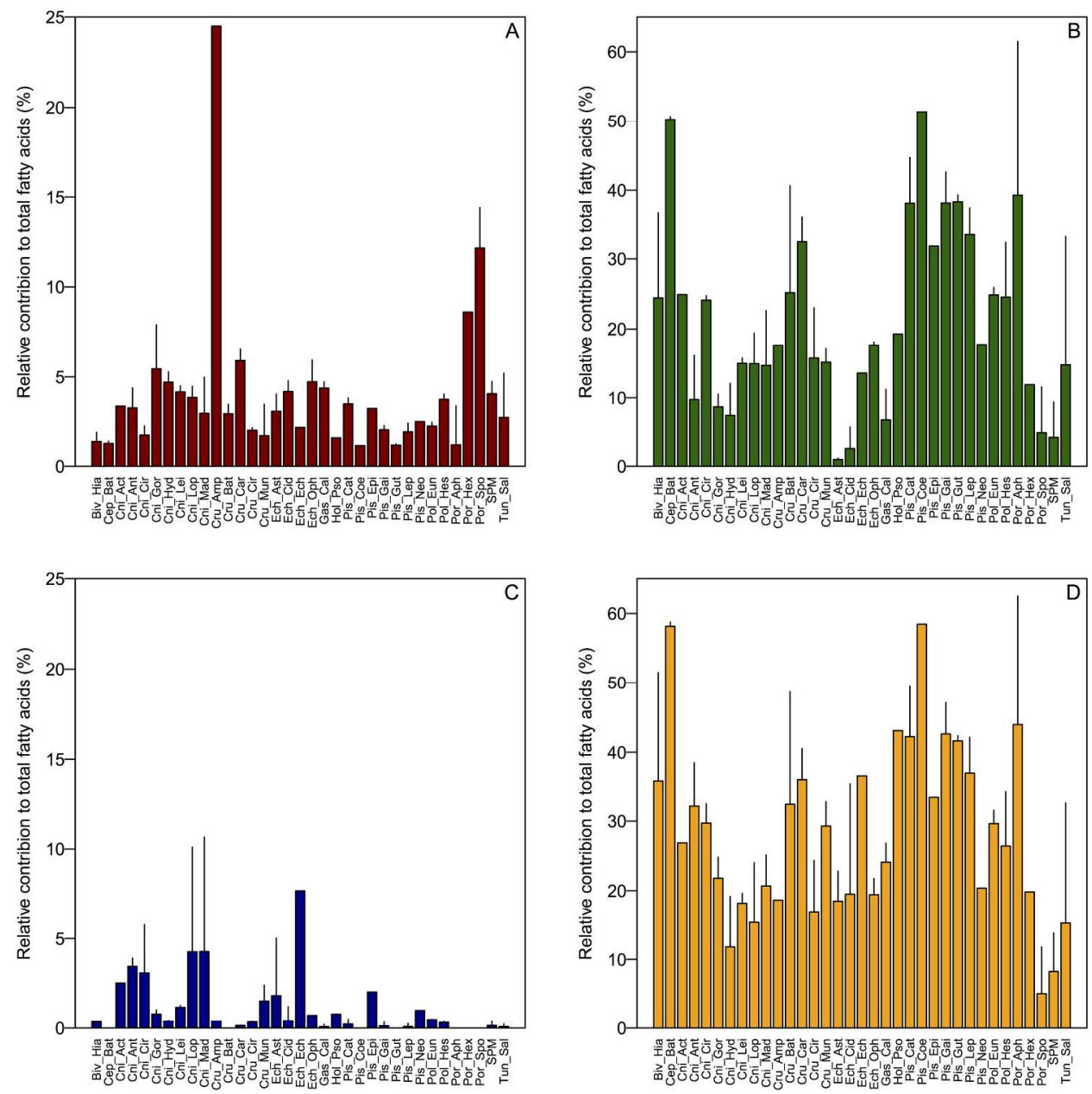

Proportion of (A) summed bacterial fatty acids, (B) summed algal fatty acids, (C) summed zooplankton fatty acids and (D) summed essential fatty acids of species of the Belgica Mounds. Errors bars indicate standard deviation calculated from the replicate samples indicated in Table 4. See Table 2 for abbreviations.

$$
228 \times 228 \mathrm{~mm}(300 \times 300 \mathrm{DPI})
$$



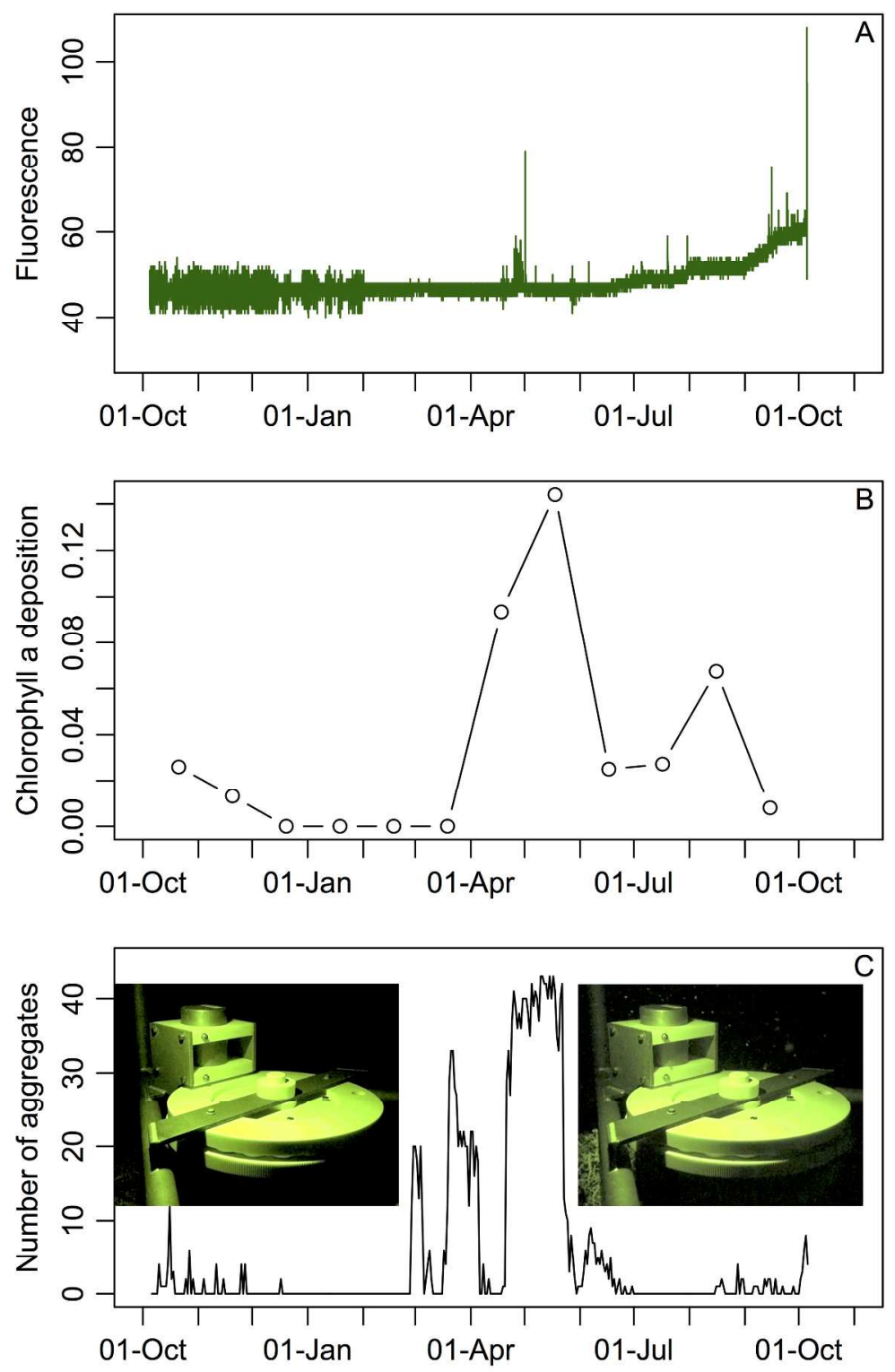

Time series from October 2011 to October 2012 of A) fluorescence signal (in relative units), B) chlorophyll a deposition $\left(\mathrm{ng} \mathrm{m}^{-2} \mathrm{~d}^{-1}\right)$ in the sediment trap and C) number of visible aggregates on a still image. The inset figure on the left shows image from period with no visible aggregates (2-Nov-2011) and inset figure on the right shows an example image from period (2-May-2012) with visible aggregates in the picture (i.e. the whitish specks in the dark top part of the inset figure).

$$
203 \times 325 \mathrm{~mm}(300 \times 300 \mathrm{DPI})
$$




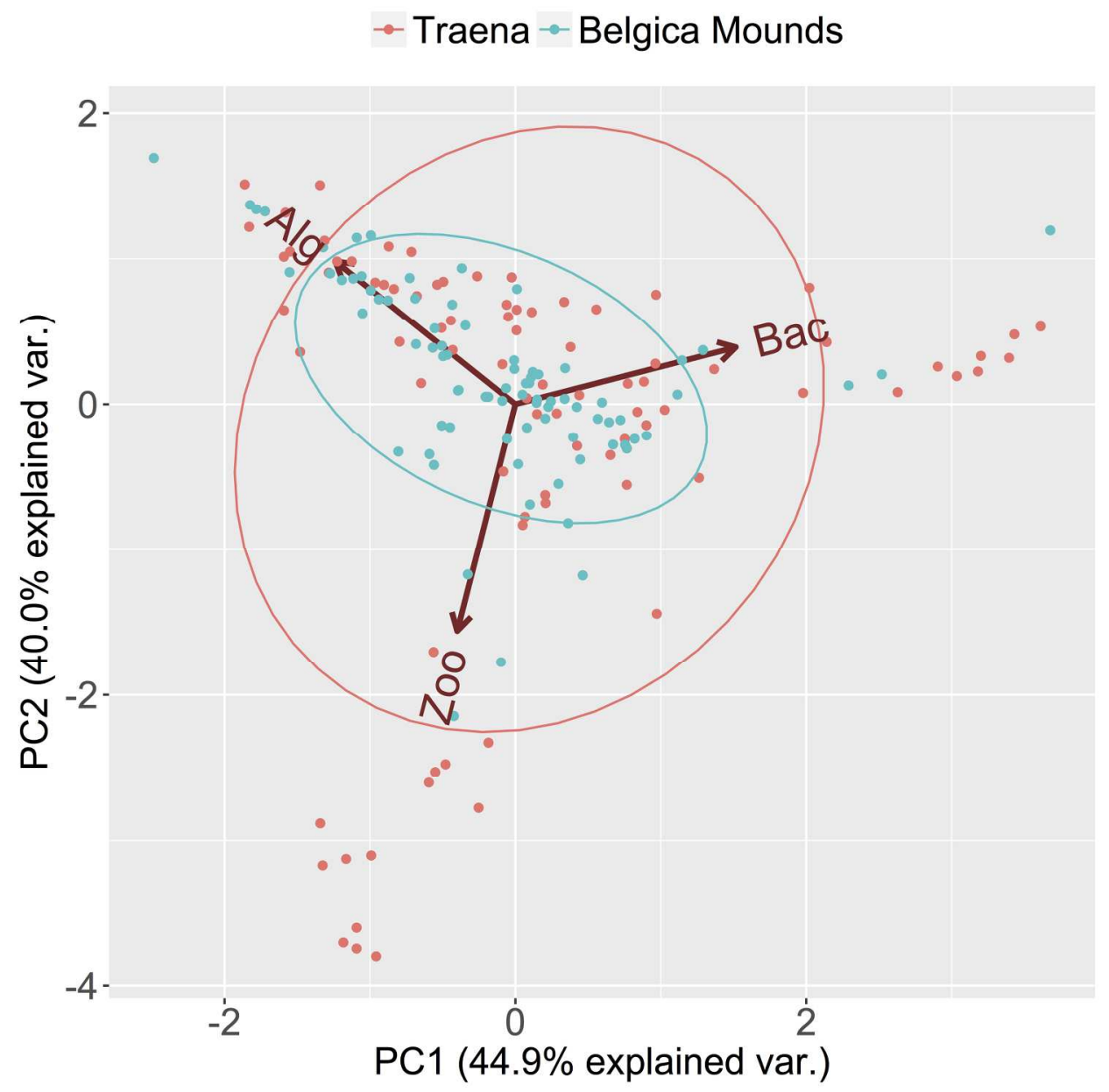

PC1 and PC2 plot of the principle component analysis of the summed specific fatty acids for algae, bacteria and zooplankton with sites Træna and Belgica mounds as group factor. Normal distribution ellipsoids are indicated.

199×199mm (300 x 300 DPI) 

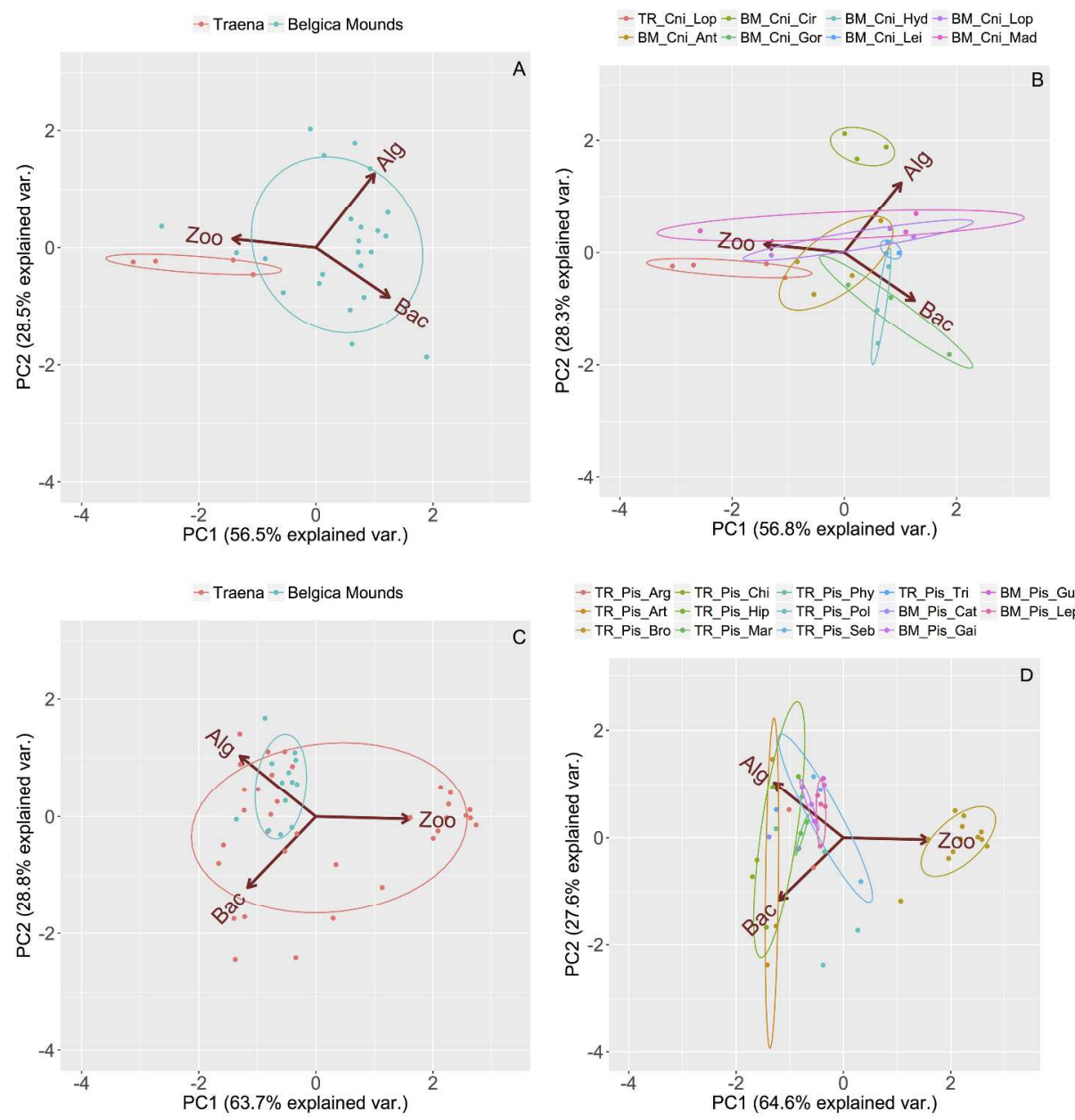

PC1 and PC2 plots of the principal component analysis of the summed specific fatty acids for algae, bacteria and zooplankton for A) Cnidarian samples with sites Træna and Belgica Mounds as group factor, B) Cnidarian samples with sites and taxa as group factor, C) Pisces samples with sites Træna and Belgica Mounds as group factor, D) Pisces samples with sites and taxa as group factor. Normal distribution ellipsoids are indicated. Abbreviations in the legends of subplot B and D are denoted as "TR_" for Træna and "BM_" for Belgica Mounds followed by the taxa abbreviation, which can be found in Table 1 and 2 for Træna and Belgica Mounds, respectively.

$170 \times 170 \mathrm{~mm}(600 \times 600 \mathrm{DPI})$ 


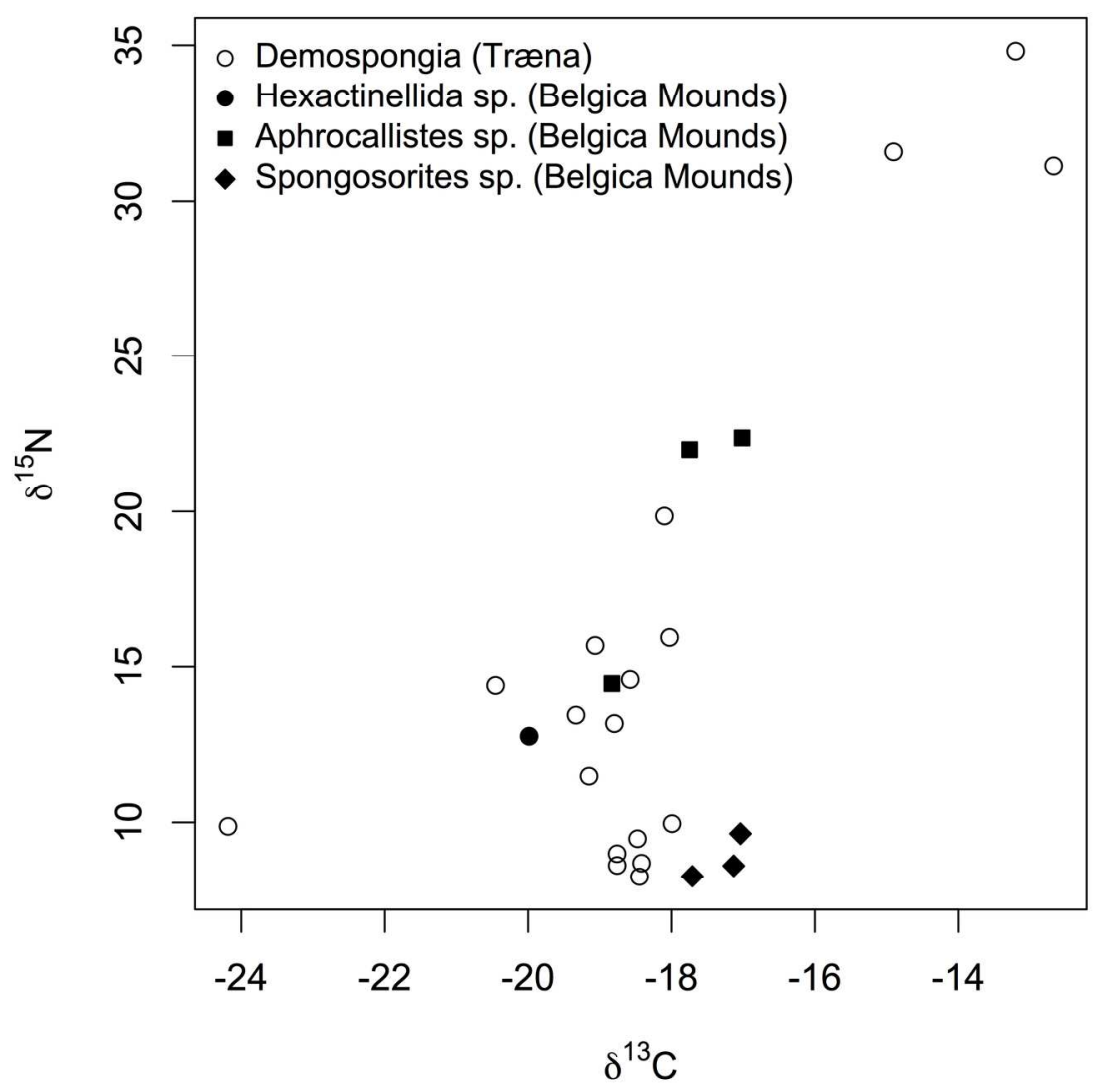

$\delta^{13} \mathrm{C}(\% \circ)$ and $\delta^{15} \mathrm{~N}(\% \circ)$ values of individual sponge samples at the Træna coral reef (open symbols) and Belgica Mounds (closed symbols).

$177 \times 177 \mathrm{~mm}(300 \times 300 \mathrm{DPI})$ 